\title{
Din Sosyolojisinde Son Gelişmeler ve Gündemdeki Tartışmalar*
}

\author{
DARREN E. SHERKAT*/CHRISTOPHER G. ELLISON"* \\ CCEVIREN: IHSAN ÇAPCIOG̈LU \\ AR GÖR, ANKARA Ü. ILAHIYAT FAKÜLTESi \\ e-mail: icapci@divinity.ankara.edu.tr
}

özet

Din sosyolojisi kurumsal ve entellektüel anlamda büyük bir genisleme sürecinden geçmektedir. Son zamanlarda üst düzey sosyoloji dergilerinde din sosyolojisi alanunda yayumlanan teorik ve ampirik makaleler, hem ilgi hem de tarışma konusu olmaksadır. Biz, öncelikle dini inanç ve bağlllkklar üzerine yapulan araşırmalardan ömekler verecegiz. Ardından, dinin politika, aile, sağlık ve mutluluk, ozzgür alan ve sosyal sermaye üzerindeki etkisini inceleyeceğiz. Son olarak da, din sosyolojisi literatüründe rasyonel tercih teorilerine ve bu perspektriflerin uygulanması çerçevesinde yapılan tartışmalara değineceğiz.

anahtar kelimeler

Rasyonel Tercih, Siyaset, Aile Sağhuğı̆, Sosyal Kontrol

\section{Giriş}

Din sosyolojisi kurumsal ve entellektüel anlamda büyïk bir genişleme sürecinden geçmektedir. Din araştırmalanna tahsis edilen sosyal bilim organizasyonlan, toplantılara katulım ve üyelik açısından daha önce görülmemiş bir gelişmeye sahne olmaktadır. Daha yakın zamanda, Amerika Sosyoloji Derneği'ne bir din sosyolojisi bölümü eklenmiştir. Üst düzey sosyoloji dergilerinde din sosyolojisi alanunda yaymlanan güncel teorik ve ampirik makaleler, hem ilgi hem de tartışma konusu olmaktadır. Aslında, 1960'lardan bu tarafa ilk kez özellikle diğer temel alanlarda uzmanlaşan bilim adamlan, din sosyolojisi alanında araştırmalar yapmakta ya da teoriler geliştirmektedirler. Bu geliş̧me, sosyal hayatta dinin öneminin azalacağı, dini organizasyonlann gücünü kay-

\footnotetext{
- "Recent Developments and Current Controversies in the Sociology of Religion", Anmual Review of Socidogy 1999, 25: 363-394.

•- Doç.Dr., Southem Illinois Üniversitesi, e-mail:sherkade@ actrvax.varderbilt.edu

‥Prof.Dr., Texas Üniversitesi, e-mail: cellison@mail.la.utexas.edu
} 
bedeceği ve bireylerin dini bağldlklannın zayfflayacağııı ön gören sekülerleşme teorilerinin beklentilerini kabul eden pek çok sosyolog açısından büyük bir sürpriz olmustur. Ancak, 1970'lere kadar tüm dünyada meydana gelen olaylar, 20. yüzylln sonunda dinin inkar edilemez bir güce sahip olduğunu göstermiştir. Birleşik Devletler'de ve başka yerlerde fundamentalist dinin yükselişi (Marty \& Appleby 1991) ile kültler ve yeni dini hareketler üzerine yapılan kamusal tartışmalar, muhtemelen, sosyal bilimcileri dinin önemini yeniden değerlendirmeye sevk eden en önemli gelişmelerdi. Aynca, din sosyolojisi ile -özellikle aile, sağtlk sosyolojisi ve sosyal hareketler gibisosyolojinin diğer alanlan arasındaki teorik ve ampirik bağlantılar, din sosyolojisine ilginin yeniden canlanmasinda önemli bir rol oynad.

Bugün pek çok ihtilaf, sekülerleşme teorilerini savunanlar ile farklı bakaş açılanyla dini davranış ve yönelimleri açılkamaya çalışan bilim adamlan arasundaki tartı̧malanda ortaya çıkmaktadır. Sekülerleşme teorisi sosyal bilimler alanında uzun bir tarihsel arka plana sahiptir ve din sosyolojisinin gelisimine önemli katkılar sağlamıştır (Hadden 1987). Aynca, sekülerleşme, kökenleri Batı aydınlanmasına kadar uzanan ve pek çok Batılı seçkinin geleneksel bilgeliğini yansitan ideolojik bir motivasyondur. (Hadden 1987, Lechner 1991, Stark \& Bainbridge 1985). Sekülerleşme teorisyenleri, sekülerleşmeye yol açan temel süreç olarak, genellikle, toplumsal düzeyde meydana gelen farkhlaşmay kabul etmekte (Dobbelaere 1985, Lechner 1991, Tschannen 1991, Chaves 1994) ancak onun içeriği ve alanı konusunda birbirinden farklı görüsler ileri sürmektedir. Tschannen (1991), sekülerleşme teorisyenlerinden yedisini (aralarında farklılaşma, çoğulculuk, rasyonelleşme, bilimcilik ve inançszliğın da bulunduğu) toplam on iki ayn boyut hakkındaki görüslerinden hareketle smiflandırmaktadır. Dobbelaere (1985), dört farklı analiz düzeyinde iki ayn sekülerleşme paradigması olduğunu iddia etmektedir. Teorinin son zamanlardaki savunuculan ise, dini "otorite" üzerine odaklanarak teorilerini yeniden formüle etmektedirler (Chaves 1994). Sekülerleşme perspektifleri ve yorumlarnun çeşitliliği, somut işletimsel hipotezlerin yetersizliği ile birleşince, bazı eleștirmenlerin bu perspektiflerin hiçbir zaman bir teori oluşturamadıklarnı iddia etmelerine yol açmıştır (Hadden 1987). Bir teori olarak statüsü her ne olursa olsun, birçok bilim adamı dini fenomenleri sekülerleşme perspektifinden hareketle açıklamaya çalışmakta ve konu ile ilgili tartışmalar devam etmektedir.

Sekülerleşme teorilerine yönelik eleștiriler, 1970'lerde evrimci fonksiyonalist teorilerin gündemden düşmesiyle birlikte ortaya çlkmaya başlamıştır. Sosyologlar, birleşik bir kollektif bilinç şeklindeki romantik görüslere ve Batı 
Avrupa'nın kültürel ve ekonomik yönelimlerini dünyanın geri kalan kısmına zorla kabul ettirme çabalarına karşı çıktılar. Tarih sosyologlan ve antropologlar, modern öncesi dünyanın çeşitli dini inançlar, pratikler ve hatta inançsızlikla dolu olduğunu gördüler (Douglas 1982). Diğer teorisyenler, farklılaşma ve hayal kınklığının, çoğunlukla, farklılaşmadan vazgeçiş ve yeni bir hayal kınklığı ile sonuçlandığını (Tiryakian 1992) ve dini kurumlanı işlevsel farklılaşmasının, siyaset, ekonomi, kültür ve toplumsal yaşamın diğer alanlan üzerindeki dini etkilere mani olmadığın iddia ettiler (Beyer 1994). Dini fenomenlerin karmaşıklı̆ının -ve dini davranış açısından bireysel tecrübelerin derin öneminin- sekülerleşme teorilerinin objektifinden anlaşılması oldukça zordu. Birçok bilim adam bu çerçeveden kurtulmak için gayretle çalışırken, Peter Berger gibi ünlü sekülerleşme teorisyenleri bile görüşlerinden vazgeçtiler (Obristian Centrory, oct. 29, 1997). Ancak, Rodney Stark ve William Sims Bainbridge'nin etkili teorik kompozisyonlanm en son noktaya ulaştırdıklan $(1985,1987)$ ve sosyal hareketler üzerine çalşsan bilim adamlannun ilgilerini dini hareketler üzerine çevirmeye başladığı (Hall 1988a, Snow 1993, Rochford 1985, Zald 1982) 1970'lerin sonlanna kadar alternatif perspektifler yoktu. Yeni teorik perspektifler ve metodolojik titizlik konusundaki çok huzlı gelişmeler, bazı bilim adamlanun rasyonel tercih teorileri ve ampirik analizlerin içine yerleştirilen "yeni bir paradigmanın" egemenliğini ilan etmelerine yol açı (Warner 1993).

Bu makalede, öncelikle dini inançlar ve bağlılıklar üzerine yapılan araştırmalar ve Birleşik Devletler'deki yönelimlerden örnekler vereceğiz. Ardından, dinin (a) siyaset, (b) aile, (c) sağllk ve mutluluk, (d) özgür alan ve sosyal sermaye konulan üzerindeki tesirlerini inceleyeceğiz. Makalenin geri kalan bölümünde ise, dinden kaynaklanan rasyonel tercih teorilerine ve bu teorilerin uygulanması çerçevesinde yapılan temel teorik tartışmalara değineceğiz.

\section{Çăgdaş Amerika da Dini Inançlar ve Bağlılıklar}

Dini inanç, katılım ve kabullerin bilimsel açıdan incelenmesi üç konu üzerinde yoğunlaşmaktadır: (a) İnanç ve bağlulıklanın dağllum, (b) inanç ve bağlllıklardaki yönelimler ve (c) dindarlik tahminleri. Birleşik Devletler'de dini inançlar kayda değer bir görünürlüğe sahiptir. Genel Sosyal Araştırma (GSS) verilerine göre; (a) Amerikalulann sadece \% 2.2'si Tann'ya inanmadı̆̆ın ifade ederken, yaklaşık \% 63'ü inancından hiçbir şüphe duymamaktadır. (b) Yaklaşı her üç Amerikalıdan biri Kitab-1 Mukaddes'in Tann kelamı ve \% 80'den fazlası vahiy mahsülü olduğunu düşünmektedir. Aynca, katulumcılardan \% 77'si cennetin, \% 63'ü cehennemin ve \% 58'i ise şeytanun varlığına inanmak- 
tadır. Soru sorma üsluplan ve ömekleme tekniklerindeki farklleklardan dolayı bu tür inançlardaki eğilimleri belgelemek zordur. Ancak, önceki araştırmalar karşlaştunlabilir ömekleme teknikleri kullanmadığı halde, Gallup verileri değerlendirildiğinde bazı dini ortodoksi ölçümlerinde (Glenn 1987, Greeley 1989 Smith 1992) çok hafif bir düşüş varmış gibi görünmektedir. Diğer taraftan, Tann ve ölïmden sonraki hayatla ilgili inançlar konusunda dikkat çekici bir istikrar gözlenmektedir (Greeley 1989, Harley \& Firebaugh 1993).

Diğer uluslar ve gönüllü çalışma gruplan ile karşılaşturldığında Amerika'daki dini katulım düzeyi ve dini organizasyonlara üyelik oranlannun yüksek olduğu görülmektedir (Verweij ve diğerleri 1997). GSS bulgulanna göre, Amerikalulann \% 61'i bir dini organizasyona üyedir. \% 29'u haftada; \% 45'i ise, ayda en az bir defa kiliseye gitmektedir. Ancak, Kilise katulum oranlarna ilişkin kesin rakamlann kişilerin kendi ifadelerine göre belirlenmesi, ciddi tartışmalara neden olmaktadır. Bazı araştırmacılar, Amerikalılann kiliseye katılım oranlan konusunda abartil rakamlar verdiklerini ve gerçek katılım oranlarınun araştırmaya katılanlann beyan ettiklerinin yaklaşık yansı kadar olduğunu iddia etmektedir. Buna göre, haftada bir din hizmetlerine katılan Amerikalulann oranı \% 22'dir (Hadaway ve diğerleri 1993). Ne var ki, dini katulım oranlan hakkında yapılan bu tür muhafazakar tahminlerdeki rakamlar bile, diğer gönüllï organizasyonlann haftalık faaliyetlerine katllmm oranlanndan daha yüksektir. Kiliseye katılan nüfusun belirlenmesinde karşılaşılan problemler, katlum raporlan ve cevaplanma yüzdeleri düşük araştırmalann ortaya çıkardığı anormallikler birlikte değerlendirildiğinde, bu araştırmalardaki abartılı rakamlann çok düsük olduğu görülmektedir (Hout \& Greeley 1998, Woodberry 1998). Aynca, dini katılım üzerine yapılan araştırmalarda, genellikle, bu konuda ciddi bir gerilemeye rastlanmamakta ya da 1960'lardaki Katoliklerle karşılaştırıldığında çok hafif bir gerileme olduğu anlaşılmaktadır (Hout \& Greeley 1987, Glenn 1987, Greeley 1989, ancak bkz. Presser \& Stinson 1998). Amerikalular dini organizasyonlara da önemli miktarda para ve zaman ayırmaktadır. GSS verilerine göre, Amerikalların bu tür organizasyonlara bağışladığı yllık ortalama miktar, hane başına 440 dolardır (Hoge \& Yang 1994). 1996 yilında en büyük 15 dini organizasyona yapılan bağışlann toplamı (kendi açıkladıklan rakamlara göre) 18 milyar dolan geçmektedir. Üstelik, en büyük on organizasyondan altısı bağış miktarlanın açıklamamıştır (Bedell 1997). Başka dini faaliyetlere ve ürünlere (ömeğin, edebiyat, müzik, giyim kuşam gibi) yapılan harcamalarla birleştiğinde bu tür bağışlar, Amerikan toplumunda dini dev bir endüstri ve ekonomi sektörünün kar amacı gütmeyen büyük bir bileşeni haline dönüştürmektedir. (Wuthnow 1991b). 
Dindarlığın en ilginç yönlerinden birisi, dini bağlleklann, rakip gruplan birbirinden uzaklaştırmasıdır. Mezhep farklılıklan ve dini çeşitliliğe dünyanın her tarafinda rastlanmaktadır. Ancak, Birleşik Devletler'de dini çoğulculuk, genellikle, dinin ayırt edici niteliği olarak değerlendirilmektedir (Tiryakian 1993). Amerika'da çeşitli kültler ve dini hareketlerle birlikte 2100 'den fazla dini grup vardır (Melton 1996). Bu gruplardan 133'ü 137 milyon taraftar ve 55 milyonu aşkın kayıth üyeye sahiptir (Bradley ve diğerleri 1992). GSS rakamlanna göre (1989-1996); Amerikallann \% 25’i kendini Katolik olarak tanıtmakta, yaklaşık \% 26'sı kendini Baptist olarak ya da (Assembly of God, Churches of Christ, Church of God in Christ, Nazarene, Pentecostal gibi) muhafazakar Protestan gruplar, \% 29'u (Episcopal, Presbiteryen, Metodist ve Luteryen gibi) Liberal ve Ilımh Protestanlar içinde kabul etmekte ve \% 9'dan fazlası hiçbir dine mensup olmadığını, \% 2.5'i Yahudi ve \% 2'si Hristiyanlik dışındaki diğer inançlara bağh olduğunu iddia etmektedir. Dini kimlik, urki ve etnik kimliklere göre farklllk göstermektedir. Afrika kökenli Amerikalılar arasında Baptist inanca sahip olanlann oran \% 54 olduğu halde, Church of God in Christ gibi muhafazakar gruplar içinde yer alanların ve Metodistlerin oranu \% 11'dir. Afrika kökenlilerin sadece \% 7'si Katolik ve \% 2'den daha azı çeşitli İslami gruplar gibi Hristiyanlık dışındaki dinlere mensuptur (Ellison \& Sherkat 1990). Etnik çeşitlilik dini çoğulculuğu da etkilemektedir. Son zamanlarda, etnik göçmen dinlerle ilgili araştırmalar yapılmaktadır (Wamer \& Wittner 1998). Dini kabullerin özellikle ülkenin belli bölgelerinde toplanması dikkat çekicidir. Luteryenler yukan orta batıda toplanurken, Katolikler kuzeydoğu ve güneybatıda yoğunlaşmaktadır. Baptistler güneye hakim durumdadır. Mormonlann en yoğun yaşadıklan yer ise, batı Intermountain bölgesidir (Bradley ve diğerleri 1992). Yaklaşık her üç Amerikalıdan biri din değiştirmektedir. Aynca, din değiştirenlerin üçte biri en az bir kez başka bir dine geçenlerden oluşmaktadır (Roof 1989). Araștırma bulgulan ve mezhep istatistiklerine göre; llml ve liberal Protestan kiliseler gittikçe taraftar kaybettiği halde, muhafazakar Protestan mezhepler, Yehova Şahitleri, Mormonlar ve hiçbir dine bağh olmayanlarda, din değiştirenler ya da diğer katılımlarla birlikte marjinal bir "büyüme" görülmektedir (Bedell 1997, Ellison \& Sherkat 1990, Hadaway \& Marler 1994, ancak bkz. Smith 1992). Ancak, yaygin kanaatin aksine, din değiştirenlerin oranunda artış yoktur (Sullins 1993).

Araştırmalar dini inanç ve davranı̧̧lann; (a) aile ve mezhep sosyalleştirmesi, (b) cinsiyet, (c) sosyal statü, (d) yaşamın rutin akışı ve yaşlanmanın bir fonksiyonu olduğunu göstermektedir. Aileler çocuklarınun dini inanç ve bağlilıkların bir taraftan doğrudan sosyalleştirme yoluyla (Hoge ve diğerleri 
1994, Kelley \& De Graaf 1997, Myers 1996, Sherkat 1998), diğer taraftan sosyal ilişkilerini yönlendirerek etkilemektedir (Cornwall 1989). Eğer annebaba aynı dine inanıyorsa, çocuklanna kendi dindarlıklanı ve dini kabullerini çoğunlukla aktarabilmektedir (Myers 1996, Sandomirsky \& Wilson 1990, Sherkat 1991). Aynca, muhafazakar Protestan ve Katolik çiftler, genellikle, ayn yaşamaya başladıklannda çocuklarnnı bağlleğını kazanabilmektedir (Nelson 1990). Muhafazakar Protestan mezhepler, üyelerini, geleneksel dini inançlarnı aktararak ve dini faaliyetlere daha yoğun katlımlanı sağlamaya çalışarak sosyalleştirmektedir. Sonuç olarak, muhafazakar dini mezheplerin üyeleri daha az dinsizlik eğilimi sergilemekte ve dini organizasyonlara daha fazla zaman ve para ayırmaktadır (Hoge \& Yang 1994, Iannaccone ve diğerleri, Sherkat 1998, Sherkat \& Wilson 1995).

Kadınlar erkeklere göre, dini organizasyonlara daha skk katulmakta, dinsizliğe daha az eğilimli olmakta ve erkeklerden çok daha fazla inancına sadık kalmaktadır (De Vaus \& McAllister 1987, Miller \& Hoffman 1995, Sherkat \& Wilson 1994). Kadın karşıtı söylemleri ve yasaklar benimsiyor görünmelerine rağmen (Peek ve diğerleri 1991), dini organizasyonlar, kadının katılımını teşvik eden ve hatta üst düzey liderlik fursatlan sunan sosyal çevre ve destek sağlamaktadır (Bartkowski 1997, McNamara 1984, Stark \& Bainbridge 1985). Aynca, genç kadınlar dini inançlar ve bağlllkllar yoluyla daha güçliu ve daha başarlh bir șekilde sosyalleştirilebilirler. Üstelik, aile içindeki yapısal konumlan, bu bağhllkklarn pekiştirilmesine ve sürdürülmesine katkıda bulunabilir (De Vaus \& McAllister 1987). Teorisyenler, kadınlar arasinda nefret riskinin daha yüksek oluşunun onlan daha dindar olmaya sevk edebileceğini de ifade etmektedir (Miller \& Hoffman 1995).

Sosyal statü, dini inanç ve bağlllklar üzerinde değişen etkilere sahiptir. Eğitim, dini organizasyonlara katılımı olumlu yönde desteklediği halde, eğitim seviyesi yükseldikçe geleneksel dini inançlann ölçümü güçleşmektedir (Iannaccone 1997, Johnson 1997, Sherkat 1998). Gelirlerine kyyasla yaptiklan katkllar düşük olsa da, gelir seviyesi yüksek olanlar dini organizasyonlara daha fazla bağıss yapmaktadır (Hoge \& Yang 1994). Ancak, yüksek gelirli bireyler, genellikle, bu tür organizasyonlara doğnudan katılmak yerine maddi destek sağlamayı tercih etmektedir (Iannaccone 1997). Aynca, eğitim düzeyi yükseldikçe dini organizasyonlardan ayrlma, din değiştirme ve dinden dönme oranlannda artış gözlenmektedir (Sherkat 1991, Sherkat \& Wilson 1995).

Dini bağlllkklar ile aile kurma, çocuk yetiştirme ve hayatın doğal akışı içinde yaşanan bir takım olaylar arasındaki yakın ilişki, dini davranışlan etki- 
lemektedir. Genellikle, boşanma ve ayn yaşama dini faaliyetleri azalttığı halde, evlilik ve çocuk yetiştirme dine yönelimi artırmaktadır (Stolzenberg ve diğerleri 1995, Thornton ve diğerleri 1992, Myers 1996, Sherkat 1998). Düzenli bir aile hayatının dini davranuşlar üzerinde olumlu tesirlere yol açtığı görülmüştür. Bireyler "yasaların uygun gördügüu” yaşlarda evlenip çocuk sahibi olurlarsa, dini organizasyonlann ebeveynlere sağladığı sosyal destekten daha fazla faydalanabilmektedir. Araştırmalar, yirmili yaşlann sonunda ya da otuzları başında çocuk sahibi olan ailelerin daha erken yaşlarda çocuk sahibi olmayanlara göre dini katulımlannın daha yüksek olduğunu göstermektedir (Stolzenberg ve Diğerleri 1995). Aym dine inananlar arasında yapılan evliliklerle karşılaştırıldığında, farklı dinlere mensup bireyler arasındaki evlilikler, din değiştirme oranlanının yükselmesine katkıda bulunmaktadır (Lazervitz 1995, Sherkat 1991, Sandomirsky \& Wilson 1990). Yaşlanma, belki de artan entegrasyon ve sosyal yardım isteği ya da hayatın anlamının üst düzeyde sorgulanmasına duyulan ihtiyaçtan dolayı dini katılımı artırmaktadır (Stark \& Bainbridge 1987). Yaşam döngüsü içinde ortaya çıkan diğer faktörlerle birlikte, arkadaşlann ve dönemin tesirlerini gösteren ikna edici değerlendirmelere rağmen (Chaves 1989), araştırmacılar, söz konusu faktörlerin yaşluarın dini katulım oranlannın artmasına etki edip etmediği konusunda birbirinden farklı görüşlere sahiptir (Frebaugh \& Harley 1997, Hout \& Greeley 1990).

Son olarak, bilim adamlan din ve coğrafi hareketlilik arasındaki ilişkinin dindarlı̆ga etkisi üzerine araştırmalar yapmaktadır. Dini cemaatlerin belli bölgelerde yoğunlaşması, genellikle, doğusu daha "dindar" ve batısı kısmen dinsiz olarak nitelendirilen Birleşik Devletler'de birkaç karakteristik ömek ortaya çıkarmıştır (Shibley 1996, Smith ve diğerleri 1998, Stark \& Bainbridge 1985). Yakan zamanda yapılan araştırmalar, daha dindar alanlara yapılan göçlerin dini katılımı ve inancın önemini artırdığın, buna karşlık, daha az dindar bölgelere göçün dini bağlلlı̆̆ı zayflattığını göstermiştir (Smith ve diğerleri 1998). Kırsal güneyden gelen Afrika kökenli Amerikalilar arasında dini katılım oranlan daha yükssektir. Aynca, bu gruplarda din değiştirme eğilimine de rastlanmamıştır (Ellison \& Sherkat 1995, Sherkat \& Ellison 1991). Coğrafi hareketlilik, genellikle, toplumsal bağlan kesintiye uğratmakta ve yeni dini hareketlere katılanlar da dahil, dini kabullerde değişikliklere neden olmaktadır (Sherkat 1991, Stark \& Bainbridge 1985).

\section{Dinin Sosyal Hayata Etkisi}

Din sosyolojisine ilginin yeniden canlanması, dini inançlar, bağlllıklar ve kurumlann sosyal hayatın diğer alanlan üzenindeki etkilerinin incelenmesine 
gösterilen ilgideki artışla birlikte gerçekleşmiştir. Din, sadece ısrarla varlığım sürdürmekle kalmamış, aynı zamanda; (a) siyasi inançlar ve bağllıklar, (b) aile ilişkileri, (c) sağlık ve mutluluk, (d) özgür alan ve sosyal sermaye konulan üzerindeki etkisini de devam ettirmiştir.

\section{Din, Sosyal Hareketler ve Siyaset}

Din ve siyaset ilişkisi üzerine yapılan araştırmalar, 1970'lerde siyasallaştınlmış Hristiyanliğın (özellikle muhafazakar yorumunun) ve Ortadoğu'daki devrimci İslami hareketlerin "yükselişi” ile birlikte yeniden huz kazanmıștır (Jelen 1998, Marty \& Appleby 1991). Birçok bilim adamı uzun süre dünya siyasetinde dinin önemini gerçekte olduğundan daha düşük göstermeye çalışmıştır. Ne var ki, İlanda, Hundistan, Sri Lanka, Filistin, Bosna ve diğer pek çok bölgede uzun ylllar devam eden siyasi çatışmalar, çoğunlukla, din kaynaklıdır (Hadden 1987, Smith 1996a). Dini inançlar, bağlllklar ve kaynaklar etnik kimliklerin inşası ve bekasında önemli birer araçtır. Aynca, onlar, Birleşik Devletler'deki sivil haklar mücadelesinden Latin Amerika'daki adil gelir dağllumuna ve Ortadoğu'daki İslami ve Siyonist hareketlere kadar diğer pek çok bölgede yaşanan etnik çatı̧̧malann önlenmesi için ideolojik ve aktüel çözümler sunmaktadır (Beyer 1994, Billings \& Scott 1994, Casanova 1994, Moaddel 1996, Smith 1996a). 1970 ve 1980 'lenin büyük bölümünde, sosyal hareketleri inceleyen bilim adamlan, sosyal hareket eylemciliği üzerindeki kültürel tesirleri göz ardı etmiştir. Ancak, kaynak hareketi teorisyenleri, Afrika kökenli Amerikallann sivil haklar mücadelesinde -kurumsal ve sembolik çözümler, liderlik, yoğun sosyal ağlar içine yerleştirilen hareketin alt yapısını oluşturan bileşenler ve yerli sermaye kaynağı sağlayan- dinin, inkar edilemez önemine işaret ettiler. Aynca, bu olay dikkatlerin sosyal hareketler ve din arasındaki ilişki üzerinde yoğunlaşmasına katkıda bulundu (Morris 1984, Oberschall 1993, Zald 1982). Sosyal hareket teorisindeki son gelişmeler, sosyal hareketler açısından kültürel kurumlann önemini vurgulamaktadır (Johnston \& Klendermans 1995, Morris \& Mueller 1992). Sosyal hareketlerin analizindeki bu kültürel dönüşüm, dini ideolojiler ve kurumlann; (a) hareket meselelerinin çerçevesinin çizilmesi için nasıl bir esas sağlayabileceği, (b) hareket görüşlerinin yansıtılmasın nasıl güçlendirebileceği, (c) hareketliliğin artması ve baskının kaldırlması için sosyal meşruiyetin nasıl oluşturulabileceği ve (d) söylemlerin, kollektif kimlikler ve grup dayanı̧̧ması için eylem ve kuruma bir temel sağlamasına yardımcı olan sosyal hareketlere nasıl uyarlanabileceğinin yeniden araştırilmasına neden oldu (Hunt ve diğerleri 1994, Oberschall \& Kim 1996, Smith 1996a). Kimlik, yapısalcı Hristiyan ideolojiler ve kurumsal kaynaklanı, 
sağ kanat rakip gruplann temel bileşenleri olduğu (Aho 1990, Barkun 1994), liberal Protestan ve Katolik gruplardan aktivistlerin kürtaj1 meşrulaştırma hareketlerine katkıda bulunduğu (Staggenborg 1991), muhafazakar Hristiyanlığı Operation Rescue (kurtarma operasyonu) gibi kürtaj karşıtı gruplara önemli sembolik ve aktüel kaynak sağladığı (Blanchard 1994, Williams \& Blackburn 1996) ve dahası dindar Katolikler ve liberal Protestanlarn Orta Amerika'da Birleşik Devletlerin politikasına muhalefet eden hareketlerin merkezinde yer aldığ (Smith 1996b), din ve sosyal hareketler arasındaki bağlantıyı inceleyen araştırmalardan elde edilen çağdaş bulgular arasındadır.

Birleşik Devletler'de dini inanç ve bağlllıklar, pornografi (Sherkat \& Ellison 1997), kürtaj (Cook ve diğerleri 1992) ve eşcinsellik (Leege \& Kellstedt 1993) gibi ahlaki sorunlara ilişkin siyasallaştırlmış inançlar üzerinde önemli bir etkiye sahiptir. Inançlann kutsal metinlerin otoritesine dayandıran muhafazakarlar ve ahlaki değerleri modern sosyal bağlamlar içine yerleştiren "ilerici" cemaat üyeleri arasındaki bariz farklılık, bazılannın, siyasallaştınlmıs ahlaki meselelerin örgütlü kamplar arasındaki "kültür savaşında" giderek daha fazla kutuplaştırldığını iddia etmelerine yol açmışır (Hunter 1991). Ancak, yakın zamanda yapılan araştırmalar, gerek dini gruplann kendi içinde ve gerekse gruplar arasında çeşitli siyasi ve ahlaki değerler konusunda bir kutuplaşma eğilimi bulunmadığın göstermiştir (Hoffman \& Miller 1998, Davis \& Robinson 1996, DiMaggio ve diğerleri 1996). Aynca, çeşitli araştırmalar, ilerici kimlikler karşısında ortodoksiliğin görünürlüğü konusunda ciddi kuşkular ortaya atmaktadır (William 1997). Bir araştırma, muhafazakar Protestanların başkanlık seçimlerinde gittikçe önemini kaybettiğini ve liberal Protestanlardan demokratlara doğru kayan bir hareketin partizanliktaki ana yönelimi oluşturduğunu ortaya koymaktadır (Manza \& Brooks 1997). Ancak, Layman (1997), muhafazakar Protestan cemaati üyelerinin 1980'lerden bu tarafa giderek daha fazla cumhuriyetçi olduğunu ve dini bağllığın cumhuriyetçi oylan gittikçe daha fazla belirlediğini tespit etmiştir. Savaş söylentileri abartılırken, çağdaş araşturmalar Birleşik Devletler'de dinin, siyasi inanç ve bağlllklar üzerinde sürekli bir etkiye sahip olduğunu ve dini inanç ve bağlllıklann siyasi inanç ve değerleri nasıl şekillendirdiğine dair yayınlarda sürekli bir artış kaydedildiğini göstermektedir (Jeeln 1998, Leege \& Kellstedt 1993, Woodberry \& Smith 1998).

\section{Din ve Aile Sorunları}

Son on yl, din ve aile arasındaki bağlantılara yönelik ilgide sunurlı bir ilerlemeye sahne olmuştur. Daha önceki bir araştırma kuşağı, aile değerleri ve pratik- 
leri konusunda Katolik-Protestan farklllkklan üzerinde yoğunlaşma eğilimindeydi (Lenski 1961). Ancak, bu farklluklarn pek çoğu, dikey hareketlilik ve Katolik etnik gruplarnn asimilasyonu, Protestan gruplar arasındaki büyük farklluk, farkl din mensuplannun birbirleriyle evlenmesi ve 1960'lardan beri Katolisizmin maruz kaldı̆̆ değişimlerden dolayı zamanla ortadan kayboldu (Alwin 1986, Ellison \& Sherkat 1993a). Son zamanlarda din ve aile ilishkisi üzerine yapılan araştırmalarda şu konular ele alınmaktadır: (a) Ergen bireyin cinselliği, (b) evlilik ve doğurganllk, (c) çocuk yetiştirme ve (d) cinsiyet rolleri.

Dini faktörler ergen bireyin cinsel tutumlanın ve üreme davranışını açıkça etkilemektedir. Hizmetlere düzenli olarak katılan, yaşamlannda dine değer veren ve cemaatsel bağlllıklann sürdüren genç kadınlann diğerlerine nazaran evlilik öncesi cinsel faaliyetleri ya da gebeliği önleyici ilaç kullanma oranlan daha düsüuktür (Brewster ve diğerleri 1998, Thornton \& Camburn 1989, Forste \& Heaton 1988, Goldscheider \& Mosher 1991, Kahn ve diğerleri 1990). Diğer cemaatlerin üyeleri evlilik öncesi cinsel ilişki ile ilgili görüşlerini liberalleştirdikleri halde, aktif muhafazakar Protestanlar bunu yapmamıştır (Petersen \& Donnewerth 1997). 1980'lerde muhafazakar Protestan inancinun ve muhtemelen True Love Waits gibi savunmac1 Hristiyan gruplann yoğun faaliyetleri sayesinde, ergen beyaz kadınlar arasinda bakire kalmayı tercih edenlerin oranında gerçek bir artı̧̧ görülmüstür (Brewster ve diğerleri 1998).

Muhafazakar Protestanlar, Katolikler de dahil, diğer dini gruplann üyelerine göre, daha erken evlenmektedir (Mosher ve diğerleri 1992, Hammond ve diğerleri 1993). Çiftlerin kiliseye katulmı ve dine düskünlügüu, evlilikteki mutluluğu ve uyumu artırnken, çatı̧̧ma (aile içi şiddet de dahil) ve aynlma riskini azaltmaktadır (Filsinger \& Wilson 1984, Call \& Heaton 1997, Ellison ve diğerleri 1999a). Dini gruplar içinde yer alma, çiftlerin birbirine bağlleğın sağlamlaştırabilir, sevgi ve özveri değerlerini artırabilir ve bencil isteklere bağlliğı ortadan kaldırabilir (Scanzoni \& Arnett 1987, Larson \& Goltz 1989). Aynca, aynı inanç evlilikleri farkl inanç evliliklerine göre, daha mutlu ve boșanma ile sonuçlanma olasuğğ daha düşük evliliklerdir (Glen 1982, Heaton \& Pratt 1990). Eşleri birbirinden ayıran teolojik mesafenin derecesi, evlilikteki mutsuzluk ve çatışma (aile içi şiddet de dahil) ile yakından ilişkilidir (Ortega ve diğerleri 1988, Curtis \& Ellison 1998, Ellison ve diğerleri 1999a). Eşlerden birinin fundamentalist ya da cemaatçi olduğu farkl inanç evlilikleri, en yüksek uyumsuzluk ve aynlma riskine sahiptir (Lehrer \& Chiswick 1993).

Dini heterogami, Katolik ve Mormonlar arasinda doğurganlik oranlannı da düşürmektedir (Lehrer 1996). Doğurganllk, muhafazakar Protestanlar arasında kısmen daha yüksektir. Bu durum, doğumla ilgili inançlardan ve dini 
bağlllık düzeylerinin yuiksekliğinden (Marcum 1986) ya da erken evlilik ve düşük sosyo-ekonomik statüden kaynaklanabilir (Mosher ve diğerleri 1992, Hammond ve diğerleri 1993). Katolikler 20. yüzylln bir bölümünde, Protestanlardan daha yüksek doğurganlik oranlanna sahipti (Westoff \& Jones 1979). Ancak, bu örnek dramatik bir şekilde değişti. Protestanlara göre Latin kökenli olmayan beyazlar arasında toplam doğurganlek oran, özellikle daha geç ve daha az sıklikla evlenme eğiliminde olan Katoliklende daha düşüktür (Mosher ve Diğerleri 1992, Sander 1993). İnançsızlar, en düß̧ük doğurganlık oranlanna ve en az çocuk sahibi olma eğilimine sahip olduğu halde, Mormonlar, diğer büyük dini gruplar içinde en yüksek doğurganllk oranun elinde bulundurmaktadır (Heaton ve diğerleri 1994, Mosher ve diğerleri 1992).

On yıllarca süren ihmalin ardından yakın zamanda yapılan araştırmalar, dinin, çocuklar ve anne-babalar üzerindeki tesirlerine yeniden ışı tutmaktadır. Örneğin, bir araştırma, annelerin ve anne tarafından büyükannelerin dindarlığın, daha olumlu anne çocuk ilişkileri ve hatta genç ergenliğine bağlamaktadir (Pearce \& Axinn 1998). Aynca, giderek artan literatür, muhafazakar Protestanlann karakteristik çocuk yetiştirme felsefeleri üzerinde odaklanmaktadır. Anne-babalan bilgilendirmek için hazırlanan popüler el kitaplannda, fundamentalist ve evanjelik yazarlar, iyi belirlenmiş anne-baba rolleri ve (eşitlikçiden çok) hiyerarşik anne-baba ve çocuk ilişkileri konusundaki tercihlerini açıç̧a ortaya koymaktadır (Bartkowski \& Ellison 1995). Bununla birlikte, muhafazakar Protestanlann fiziksel cezayı savunma ve kullanma eğiliminde olduklan, fazlasıyla abartuludır (Ellison \& Sherkat 1993b, Ellison ve diğerleri 1996). Eleştirmenler Evanjelizmin çocuk yetiştirme konusundaki otoriter ve yanlş̧ uygulamalanndan kaygı duysalar da (Greven 1990, Capps 1995), bu tür endişeler abartılı olabilir. Dindar çocuk yetiştirme kılavuzlan, fiziksel cezanun nasıl yumuşatılacağına dair özenli bilgiler sunmaktadır (Ellison 1996). Aynca, muhafazakar Protestan aileler, çocuklanna daha az kızmakta ve sevgilerini sözel ve davranıssal olarak daha sık dile getirmektedir (Wilcox 1998). Evanjelik babalar, özellikle daha dindar olanlar, çocuklanyla diğer babalardan daha fazla nitelikli vakit geçirmektedir (Wilcox 1999). Belki de bu nedenlerden dolayı, geçenlerde yapılan bir araştırmada, muhafazakar Protestan çocuklar açısından fiziksel cezanın ortaya çıkardığı sistemli olumsuz sonuçlan gösteren herhangi bir bulguya rastlanmamıştır (Ellison ve diğerleri 1999b).

Dini inançlar ve bağlliklar, cinsiyet rollerinin oluşturulması ve pekiştirilmesi açışından merkezi öneme sahiptir. Bilim adamlan, geleneksel dini inançlar, düzenli dini katılım ve muhafazakar Protestan ve Mormon bağlan- 
nun, ataerkil cinsiyet rollerini güçlendirdiğini tespit etmiştir (Hertel \& Hughes 1987, Peek ve diğerleri 1991). Aynı zamanda, muhafazakar Protestanlar arasunda cinsiyet tutumlan konusunda diğerlerinden çok daha fazla heterojenlik vardır (Gay ve diğerleri 1996). Muhafazakar Protestan kadınlann -özellikle benzerlik (homogamous)* evliliği yapan ve genç yaşta çocuk sahibi olanlanniş gücüne katulımlan diğer kadınlardan daha düşük olasına rağmen (Lehrer 1995, Sherkat 1999); giderek artan saylda muhafazakar Protestan kadının ev dışında çalışması, din adamları ve kilise görevlileri arasında gönüllü hizmet ve ideolojik meşguliyetlerin artmasına yol açmıştır (Iannaccone \& Miles 1990, Demmitt 1992). Aynca, ev işlerinde cinsiyet aynm, benzer (homogamous) evanjelik çiftler arasında diğerlerine nazaran biraz daha belirgin olduğu halde, bu fark en düsük düzeydedir (Ellison \& Bartkowski 1997). Üstelik, etnografik araştırmalar, evanjelik ailelerde kararlann, çoğunlukla, eşlerin yoğun iş birliği ve müzakeresi sonucunda alındığın göstermektedir (McNamara 1984, Bartkowski 1997). Dahası, muhafazakar dini gruplardaki kadinların rolleri, doktrinler ve kurum kültürleri kadınlan marjinalleştirdiğinde bile, ciddi bir kanş̧ılık ortaya çıkarmaktadır. Çeşitli araştırmalar, muhafazakar Protestan ve Yahudi mezheplerde kadınlann yerine getirdiği ve hatta yetkili konumda olduğu pek çok görev bulunduğunu ortaya çıkarmıştır (Stacey \& Gerard 1990, Davidman 1990, Pevey ve Diğerleri 1996, Griffith 1997).

\section{Din, Sağlık ve Mut/uluk}

Son yllarda, din, sağlık ve mutluluk üzerine yapılan multidisipliner araştırmalarda ilerleme kaydedilmiştir. Bir ya da daha fazla araşturma değiş̧kenine bağh olarak, birçok konu üzerinde zamanla tekrarlanan gözlem ve incelemelere dayalı veriler, ileri analitik teknikler ve birden fazla bağımsız değişkenin dahil edildiği aynntılı denetimler kullanan araştırmalar, ölüm dahil, çeşitli zihinsel ve fiziksel sağlık sonuçlan üzerinde dini katılımın son derece olumlu tesirleri olduğunu göstermektedir (Hummer ve diğerleri 1999, Idler \& Kasl 1992,

\footnotetext{
- “Eş seçiminde iki temel ilke vardır: 'Benzertik (homogami) ilkesi'ne göre, sınurl bir bireyler gnubu içinde yaş, ırk, din, etnik köken, toplumsal sınf, eğitim ve kişilik benzerliklenine göre seçim yapulr. Benzerlik ilkesi benzerlerin birbirni çektiği gerçeği üzenine kunulmuştur. Buna karşllk 'Bütünlenme (heterogami) ilkesi' eşlerin özellikle kişilik açısından farkh ve tamamlayıcı özellikleri nedeniyle seçildiğini savunur. Bu illke karşıtların birbirini çektiği gençeğine dayanmaktadır. Araşurmalar hangi ilkenin daha çok uygulandiğın ortaya koyamamışur. Ancak, benzerlik ilkesinin daha geçerli olduğu yolunda izlenimler vardır. Bu ilkenin daha geçerli olması, böyle bir seçimin sosyo-ekonomik sınff, din ve eğjtim gibi alanlarda daha az çauş̧maya yol açması, özcllikle evliliğin ilk ylllannda kaŗ̧lıklı toplumsallaşma sürecinin daha kolay olması nedeniyle olabilir. Aynca anne baba isteği ve toplumsal basks da benzerlik ilkesi doğnultusundadır". Serpil Aytaç-Nuran Bayram, Ünizersite Gendigizinin $\dot{I}_{\xi}$ we $E_{\xi}$ Segimin deki E tkin Kriterlerinin A nalizik Hijerarşi Sürea (AHP) İle A nalizi, http://www.isguc. org/isvees.htm., 08. 05. 2003. (çev.)
} 
Musick 1996, Oxman ve diğerleri 1995, Strawbridge ve diğerleri 1997 , Williams ve diğerleri 1991). Durkheim'in kullandığı birleștirici ve düzenleyici güç gibi dini terimleri geliştiren bilim adamlan (Levin 1996, Ellison \& Levin 1998), dinin sağllk ve mutluluğu etkileyebileceğinden hareketle, aşağıdakiler dahil, çeşitli süreçler üzerinde yoğunlaşmaya başladılar: (a) Sağılklı davranı̧lar ve bireyci yaşam tarzlan, (b) sosyal bütünleşme ve sosyal destek, (c) psikolojik kaynaklar, (d) davranış bozukluklan ve çaresizliklerin üstesinden gelme, (e) çeşitli olumlu duygular ve sağlkkh inançlar.

Dini katulım, hastalık riskini azaltan yöntemlerle bireysel davranı̧̧lan düzenleyerek zihinsel ve fiziksel mutluluğa katkıda bulunabilir. Bu konuda iyi belgelenmiş bir örneğe göre, dini katlum ve inanç, alkol, sigara, madde ve uyuşturucu kullanımı gibi kronik rahatsıllklarla ters orantuldır (Koenig ve diğerleri 1994, Troyer 1988). Aynca, pek çok dini grup, (riskli cinsel pratikler, yasal olmayan hal ve hareketler gibi) çeşitli sapkın davranış türlerine engel olan, ailevi konularda rehberlik eden ve çeşitli stresli olaylar ve durumlara maruz kalmayı azaltabilecek yöntemlerle yaşam tarzı tercihlerini doğrudan yönlendiren öğretilere sahiptir (Ellison 1994).

Dini cemaatler, sosyal faaliyet ve karşulkلl etkileşim için düzenli fırsatlar sunmakta ve böylece dostluk tohumlannen ekilmesine uygun verimli alanlar hazırlamaktadır. Aynı dine inananlann oluşturduğu gruplar, yaşamın akışı içinde stresli durumlarla karşılaşan arkadaş ve üyelere desteğin yanı sıra, ihtiyaç sahiplerine yardıma aracllk eden gayri resmi sosyal destek ve duygusal yardım kaynaklandır (Tylor \& Chatters 1988, Ellison \& George 1994). Birçok cemaat, dini danı̧̧manlğğ yanında, muhtaçlara yardım amacıyla düzenlenen (yoksullukla mücadele, tıbbi danışmanlk ve aile hizmetleri gibi) resmi programlann sponsorluğunu üstlenmektedir (Caldwell ve Diğerleri 1992, Kimble 1995). Dini gruplar, üyelerinin birbirlerini sevmelerine, değer vermelerine ve sayg1 duymalanna yol açacak bir cemaat hissinin gelişimine katkıda bulunabilir.

\section{Özgür Sosyal Alan ve Sosyal Sermaye}

Giderek artan literatür, dini gruplann, bazı marjinalleştirilmiş gruplar açısından "özgür sosyal alan" işlevi görebileceğini ve grup üyelerini araçsal amaçlara yönlendirebilecek "sosyal sermaye" ile donatabileceğini göstermektedir (Greeley 1997, Warner 1993). Sosyal sermaye; (a) davranışı belirli bir yöne doğru kanalize eden ve diğerlerinden uzaklaşturan normlar ve değerler ortaya koyarak, (b) bilginin dolaşımun hızlandırarak, (c) gerek uzun vadeli zaman ve enerji yatınmların teşvik ederek, gerekse ilişkileri karşllkhı bağımlluk, güven 
ve çift taraflı zonunluluk ilkesi çerçevesinde yeniden düzenleyerek olumlu sonuçlarn ortaya çikmasına katkıda bulunabilir (Coleman 1988, Portes 1998). Birleşik Devletler tarihi boyunca, çeşitli dini gruplar, kültürel ve/veya yapısal marjinalliğin ortaya çıkardığ koşullara, yeni dini organizasyonlar yaratarak, yeni spiritual ifade şekilleri geliştirerek ve mevcut dini kurumlar içinde yanı özerk alanlar olusturarak uyum sağladular (Warner 1993). En genel anlamda bu "özgür alanlar" aşağıdaki fonksiyonlan kısmen ya da tamamen yerine getirmektedir. (a) Ruhsal ve psikolojik tatmin ihtiyacını karșlama, (b) dini doğru anlama ve etnik ve diğer grup kültürleri ve dahası kimliklerin ifade edilmesi için uygun fırsatlar sunma, (c) diğer alanlarda göz ardı edilen grubun bazı ihtiyaçlannun açıkşa dile getirilmesi, (d) ortak çıkar bilincinin geliştirilmesi ve kollektif hareketin desteklenmesi (Warner 1997). Bu farkl olgularn sayssız örnekleri arasında yer alan (Metropolitan Toplum Kilisesi gibi) organizasyonlar, eşcinseller ve lezbiyenlerin ruhsal ihtiyaçlan ve toplumsal kayg1lan, ana cemaatler içindeki çeşitli oluşumlar (Warner 1995), bir dizi pagan ve Wiscan** topluluklan da içine alan çeşitli feminist spiritual gruplaşmalar (Griffin 1995) ve farklı rki/etnik azınlklar tarafından kurulan gruplar üzerinde odaklanmaktadir.

"Özgür alan" olarak dinin en ünlü örneği, muhtemelen, Afrika kökenli Amerikallarnn canlı kilise geleneği içinde yer almaktadır. Nesiller boyu Afrika kökenli Amerikalılar arasinda en önemli sembolik mevkileri isgal eden dini kurumlar, kollektif benlik hizmeti ve grup gelişimi, ahlak reformu, sosyal hizmet dağtım, grup liderliği ve siyasi hareketlilik gibi konularda temel kaynak vazifesi görmüştür (Lincoln \& Mamia 1990, Morris 1984, PattilloMcCoy 1998). Bir araştırma, birbirinden farkh ı̧ağdaş göçmen cemaatlerin -Birleşik Devletlerin büyük kentlerinde dini gelenekleri (yeniden) kurma ve (yeniden) canlandırma gibi- karmaşık rollerini açıklamaktadır (bkz. Warner \& Wittner 1998). Bu araşturmalar birlikte ele alındığında, -farklı inanç geleneklerini temsil eden- göçmen cemaatlerin, genellikle, sosyal ağlar, bilgi ve yetenekler ve aynca yeni gelenlerin psikolojik uyumunu ve dikey hareketliliğini kolaylasttran diğer kaynaklara sahip olduğunu göstermektedir (Bankston \& Zhou 1996, Kwon ve diğerleri 1997, Chong 1998, Warner \& Wittner 1998, Yang 1998).

Ayrca, eskiden beri dinin, pek çok nedenden dolayı suç ve sapmaya engel olduğu düsünülmektedir: (a) Dini normlann ve ahlaki mesajlann içselleştirilmesi, (b) ilahi ceza korkusu (sözde "cehennem ateşi"nin etkisi), (c) aynı

* Hristiyanluk'tan önce Ingiltere, Irlanda ve Fransa'da yaşamış eskj Seltik dönemi papazlannun mirasçısı olduklanna inananlann oluşrunduğu bir hareket (şev.). 
dine inananlar açısından sosyal yapurumların oluşturduğu tehdit, (d) dini topluluklann kendi içindeki referans gruplan tarafından kabul görme isteği ve (e) dini faaliyetlere ve oluşumlara katularak sapkn işlerden uzak kalma düsüncesi, bu durumun diğer muhtemel dini sonuçlan arasındadır (Cochran ve diğerleri 1988, Grasmick ve diğerleri 1991, Evans ve diğerleri 1995, Stark \& Brainbridge 1997). Ancak, bu alanda yaplan araştırmalar, dinin suç ve sapmaya nasil engel olduğu ve hatta, engel olup olmadığı, konusunda farklı görüşler ortaya çıkarmıştır. Bazı araştırmacılar gerçekte bu tür bir ilişkinin olmadı̆̆ı ima ederken (Cochran ve diğerleri 1994), diğerleri dinin etkisinin suçun tipine ya da ciddiyetine veya suçla ilgili dini normlann (seküler normlar karşısında) ayırt ediciliğine bağl olduğunu iddia etmektedir (Tittle \&zWelch 1983). "Ahlaki topluluklann" savunuculan, dinin sapmayı önleyen gücünün, dindarlk (Welch ve diğerleri 1991, Stark 1996) ya da dini homojenlik düzeyleri son derece yüksek olarak bilinen (okullar, cemaatler ve topluluklar gibi) ortamlarda doruğa ulaştı̆ğı ifade etmektedirler (Ellison ve diğerleri 1997).

Yakın zamanda yapılan araşturmalar, dini farklleklan suç ve sapmaya göre açıklamaktadır. Ortalama olarak muhafazakar Protestanlar, suç türlerini diğerlerinden daha fazla ciddiye almakta (Gurry 1996) ve suçlular aleyhine daha sıkı ve cezalandıncı yaptınmlan desteklemektedir (Grasmick \& McGill 1994). Geçenlerde yapılan provakatif araştırmalar da, hapishanedeki dini programlann ve bireysel dindarluğın, mahkumlar arasındaki davranış bozukluklannı ve suç işleme olashlğın azaltabileceğini göstermiştir (Johnson ve diğerleri 1997). Din ve suç ilişkisinin karmaşık doğasınun daha iyi anlaşılmastnu sağlama, gelecekteki araştırmalann önemli bir önceliği olmalidır.

Dinin güdüleyici rolüne gösterilen ilgi son yllarda toplumcu temalarla kısmen daha fazla ilgilenilmesi ve inanç grupları üzerindeki prososyal etkilere yeniden dönülmesi ile birlikte tamamlanmıstır. Laboratuar ve alan tecrübeleri genellikle dinin gönüllü yardım davranı̧̧lan ya da bireysel diğergamllk üzerinde çok az yönlendirici olduğunu bildirmesine răgmen (Baston ve diğerleri 1993), çeşitli araşturmalar çok sık dua ettiğini ifade eden katulumcılann mülakatçlar tarafından daha "dost canlıs" ve daha işbirliğine açık kişiler olarak değerlendirildiklerini ortaya koymaktadır (Morgan 1983, Ellison 1992). Pek çok dini topluluk, çok çeşitli pragmatik ve teolojik nedenlerle gönüllï davranışlan ve hayır kurumlann desteklemektedir. Bu konuda yapılan bir araştırma, dini grupların, üyelerini prososyal meşguliyetlere nasıl kanalize ettiğinin yanı sıra, büyük hayırseverlik sektörü içinde dini ve dini açıdan desteklenen organizasyonlann seçkin konumunu belgelemektedir (Wuthnow 1991a). Bireysel düzey araşturmalan, -kilise üyesi gruplar ve bütün topluluk içinde- 
kiliseye düzenli olarak katılanlarn gönüllü faaliyetlere daha fazla zaman ayrrdiğını sürekli olarak rapor etmektedir (Wilson \& Janoski 1995).

Aynca, kilise dışından yetişkin liderlerin ve din adamlannın rehberliğin$\mathrm{de}$, kilisenin sponsorluğunu üstlendiği gönüllülük ve yardım kampanyalan, çoğunlukla gençleri, kan verme, evsiz sığınmacılara destek olma, fakir ve yaşllara yardım programlan vs. gibi konularda harekete geçirmektedir. Böylece, sivil bağhllkk ve başkalarına yardım üzerine temel dersler verilmiş olmaktadır (Donahue \& Benson 1995, Greeley 1997, Wuthnow 1995). Dini sosyalleștirme, genellikle daha geniş nitelik ve amaca sahip konulara doğru yönlendirilmektedir (Donahue \& Benson 1995). Dini topluluklar gençleri uzun menzilli hedefler, kararlllk ve kurallara uyma üzerinde odaklanmaya özendirebilir. Aynca, onlar yetişkinleri gençlerin yaşamına uzun vadeli yatınmlar yapmaya teşvik edebilir. Aslunda, dini kurumlar, gençleri sevgi ile bir araya getiren ve düzenli olarak yetişkin rollerini öğreten nadir sosyal ortamlar arasundadır (Ellison \& Muller 1996). Bu tür dini etkiler özellikle ergenlik döneminde ve anne-baba etkisinin çoğunlukla azaldığı yetişkinliğin erken dönemlerinde önemlidir. 1960'lardan 1970'lerin başlarna kadar çok sayda araştır$\mathrm{ma}$, Katoliklerin ve eğitime karşı çıkan gruplann değerler yoluyla nasıl sosyalleştirilebilecekleri üzerinde odaklanarak dini bağldlklann yaşam fırsatlan üzerindeki etkisini inceledi. Ancak, Katoliklerle Protestanlar arasindaki farklleklann giderek azalması ve eğitsel başan konusunda diğer dini farklleklan incelemek için yeterli teorilerin geliştirilememesi, bu araşturma gündemininin 1980'lere kadar gelişimini engelledi (Darnell \& Sherkat 1997). Yakın zamanda yapılan araştırmalar, eğitsel meşguliyetleri destekleyebilecek ya da engelleyebilecek değerler üzerinde yoğunlaşarak din ve eğitsel başan arasındaki ilişkiye gösterilen ilginin yeniden canlanmasına yol açtı. Amerika'daki lise öğrencileri üzerinde kısa süre önce gerçekleștirilen bir araştırma, dini faaliyetlere düzenli olarak katılan öğrencilerin okul ödevlerine daha fazla zaman ayırma eğiliminde olduğunu, derslerini daha az aksattıklannı ve dinsiz arkadaşlanndan daha önce mezun olduklarnu tespit etti (Ellison \& Muller 1996). Saylan giderek artan araştırmalar, Katolik okul gruplan içindeki sosyal sermayenin ayrrt edici niteliklerini incelemekte ve onlann çok çeşitli eğitsel ve sosyal sonuçlar üzerindeki olumlu etkilerini belgelemektedir. Aynca, dini katulumin, kursal kesimden gelen Afrika kökenli Amerikalular ve göçmen gençler arasında eğitsel başanyı artırdı̆ııı ve onlan muhalif genç kültürlerden uzaklaş̧ırdı̆ğın gösteren destekleyici kanutlar bulunmaktadır (Bankston \& Zhou 1996, Freeman 1986). 
Bununla birlikte, kültürel azınliklann normlan ve değerleri bazen devlet eğitimini savunanlann değerleriyle çatışmakta ve mağdur gruplar seküler eğitimin asimile edici etkilerine karşı kendilerini savunmak için özgür sosyal alanlan kullanmaktadır. Daha önceki dönemlerde, Katolik okullar bu amaçla kurulmuştu. Günümüzde, kültürel çatışmanun en önemli boyutu, fundamentalistlerin ve envanjelik Protestanlann "seküler hümanizm" in kuşattığı yabancı ve düşman kurumlar olarak gördükleri için devlet okullanndan uzaklaşmalandır (Sikkink 1999). Bununla birlikte, bazı muhafazakar Protestanlar, evde eğitim ve Hristiyan akademileri de içine alan çeşitli alternatif eğitim stratejileri geliştirmeye çalışmaktadır. Bazı araştırmalar fundamentalist okulların yalıtılmışlığın ve sertliğini vurgulama eğiliminde olduklan halde (Peshkin 1986, Rose 1988), diğer bazlan egemen eğitim kültüründen kaynaklanan normlann ve stratejilerin ayst edici birlikteliğine işaret etmektedir (Wagner 1990). Bununla birlikte, pek çok muhafazakar Protestana göre, devlet okullannun kültürel açıdan yabancılaştıncı özelliği, kesinlikle devlet eğitiminden uzak durmayl gerektirmemektedir (Sikkink 1999). Aksine, dindar muhafazakarlar ve Hristiyan haklan savunuculan, eyaletlerde ve ülkenin değişik bölgelenindeki yerel okul yöneticilerinin seçiminde güçlü adaylar arasında yer almakta ve eğitim müfredatı, ders kitaplan, sansür ve diğer siyasi sorunlarla ilgili tartışmalar üzerinde belirleyici rol oynamaktadır. Ne var ki, bazı muhafazakar Hristiyanlar çocuklanı sekuiler yüksek eğitim kurumlanından uzaklaştırmaya çalışmaktadır. Biblical Inerrantist (kutsal kitabın yanılmazlığını savunan) anne-babalar ve gençler, liderlerinin uyarılanna önem vermektedir. Ömeğin, fundamentalist gençler arasında kolej eğitimi ve liselere hazırlık dersleri alanlann oranunda ciddi bir azalma görülmektedir. Aynca, inerrantist anne-babalar, çocuklannın ortaokul sonrası eğitim almasına sıcak bakmamaktadır (Darnell \& Sherkat 1997, Shaerkat \& Darnell 1999). Gelecekte yapilacak araştırmalar, farklı kültür gruplanın yaşam alanlannı ve üyelerinin yaşamlannda meydana gelen değişimlerin önemini incelemeye devam etmelidir.

\section{Rasyonel Tercih Teorileri ve Din}

On yldan fazla bir süre önce Wuthnow (1988: 500) din sosyolojisinin “... tümevarım yöntemine dayalı ampirik araştırmalar ve alt uzmanlık dallan konusunda, teorik olarak bütünleştirici kavramlanın tanımlanmasına yönelik girişimlerden daha hızlı bir ilerlemeye sahne olduğunu" belirtmişti. Günümüzde bu ifade daha az doğrudur. Dini inançlar, bağllliklar, kurumlar ve bunlarn önemi konusundaki ampirik bulgulann çokluğu; bu alanı yeni teorik perspektiflere açık hale getirmiş ve 1970 'lerin sonlannda sızmaya başlayan 
küçük teorik akımlar 1990'lann başlanna kadar büyük bir sele dönüşmüştür. Din sosyolojisinde en dikkat çekici ve tartışmalı teorik gelişmelerin kaynağı, rasyonel tercih teorileri olmuştur (Young 1997). Din ile ilgili masyonel tercih düşüncesinin iki ekolï vardır. Arz-yönü teorisyenleri, dini değerin kollektif üretimi üzerinde etkili olan zorlaştuncı ve kolaylaştıncı faktörlerin önemini vurgulamakta ve dini metalann değişmeden kalmasımı sağlayan belli baş̧ ayncaliklara sahip olduklarını iddia etmektedir. Talep-yönü teorisyenleri ise, değişen önceliklerin ve toplumsal baskılann bireylerin tercihleri üzerindeki etkisinden bahsetmektedir. Bütün rasyonel tercih perspektiflerinin merkezinde dine uyarlanan piyasa benzetmesi vardır. Aşağıdaki önermelere bu konuda yapılan araştırmalarda sıkça rastlanmaktadır: Dini piyasalar tabiatüstü karşılıklar açısından borsa işlevi görmektedir (Stark \& Bainbridge 1985, 1987). Diğer metalar gibi dini metalar da üretilir, seçilir ve tüketilir. Tabiatüstü karşllklann ve açıklamalann doğruluğu ya da yanlışhğı kanitlanamaz. Dolayssıyla dini metalar risklidir. Sosyal ilişkiler dini metalarla ilgili en uygun bilgi kaynaklandır ve onlann değeri konusunda tüketicilerin kaygılanının giderilmesine katkıda bulunur. Karşllklann ve açıklamalarn değeri konusundaki tereddütler onlann değerini düşürürken bireylerin dini yatınmlann çeşitlendirme ihtimalini artırr (Iannaccone 1995a, Stark \& Bainbridge 1987, Stark 1996b). Dini organizasyonlar kendilerini dini değer üretimine adamıs firmalardır. Cemaatler, müşteriler için değer üretmekle görevli müteşebbis satıcılar (papazlar) tarafından yönetilen imtiyaz sahipleridir. Firmalar sunduklan ürün çeşitleri ile sınurlidır ve sadece (Baptistler gibi) kurumsal hiyerarşiden yoksun olanlar ya da (Roma Katolikleri gibi) çoğulculuğa uygun kurumsal bağhllğın gelişimine katkuda bulunanlar bu tür bir çeşitliliği sürdürebilirler (Stark \& Bainbridge 1992, Iannaccone 1991, Stark 1998).

\section{Dindar insan Sermayesi}

Iannaccone'in (1990) dindar insan sermayesi teorisi hem ilham hem de tartı̧̧ma kaynağı olmaktadır (Bruce 1993, Spickard 1998). Bu teoriye göre dini katılım, bireylerin dini sermaye stoklann oluşturur. Dolayssıla dini sermaye -doktrinler, ritueller, kutsal şeyler gibi benzer ve bilinen bir formda- gelecekteki dini kollektif eylemler için dini değer üretmek amacıyla kullanulır. Alşslmış dini ortamlar dini sermayenin etkili kullanumın kolaylaştırarak dini üretimi artınr. Yabancı dini ritüeller, anlayışlar ve topluluklar ise dini değerin kollektif üretimini zorlaştırır. Ģ̈̈nkü bu tür ortamlarda dindar insan sermayesi etkili bir şekilde kullanılamaz. Tecrübeli ahçılann alışımış malzemelerle lezzetli yemekler yapabilmesi gibi iyi kullanulan dini cemaat üyeleri de kyymetli 
dini tecrübeler üretebilir. Bütün arz-yönü teorilerinde olduğu gibi önceliklerin değişmez olduğu ve sadece dini değer üretme kapasitesinin değişebileceği kabul edilir. Aynca, dini üretim konusundaki temel sıkıntı, bireylerin ya da topluluklann elinde bulunan insani sermayenin miktandır. Çok istediklen takdirde bireylerin dini tercihleri konusunda özgür olduklan kabul edilir ve dini tüketimle ilgili her hangi bir olumsuz tüketim gereksiz harcama olarak değerlendirilir (Iannaccone 1992, 1994).

Iannaccone (1990) bu teoriyi çeşitli dini fenomenleri açıklamak için kullanur. Öncelikle, insani semaye stoklannun bireylerin dini kabullerinden vazgeçme yeteneğini sınurlandırdığı kabul edilir. Şayet din değiştirme hadisesi gerçekleşirse; bu durumda -eldeki insani sermayenin kullanulabileceği- benzer bir mezhep aranacaktur. Bundan dolayı Metodistler, Katolikler ya da Hindular gibi oldukça yabancı dini geleneklerden ziyade Presbiteryenler ya da Baptistler gibi benzer gruplara dahil olma eğiliminde olmuşlardır. Gençlerin dini kabullerini değiştirme olasllkklan daha yüksektir. Çünküi onlar dini inançlanna daha az yatınm yapmışlardır. Kollektif değer üretme kapasitesinden yoksun olduklan için farkh dini gelenekten gelen çiftlerin dini katulımlan kasa süreli olacaktır. Dini görevler konusunda görece uzmanliklanndan dolayı, kadınlann dini katulım açısından erkeklerden daha üretken olduklan iddia edilmektedir. Aynca zaman ve paranin dini organizasyonlara kısmi katkısı bu genel çerçeve kullanularak açıklanmaktadır (Iannaccone 1997). Stark (1996b) insan sermayesi teorisini kısmen Roma İmparatorluğunda Hristiyanhğın Yahudiliğe kaymasın açıklamak için kullanmaktadır -Hristiyanlık Yahudi bir temel üzerine kurulduğu için Yahudiler bütünüyle yeni dini sermaye stoklan geliştirmek zorunda kalmamışlandır. Aslında alışılmış dini geleneklerden kaynağın alan yeni dini hareketler bütünüyle yeni dini felsefeler içinde yapılanan ya da yabancı çevrelerde etkili olmaya çalışan hareketlerden daha başanlı olmaktadir (Stark \& Bainbridge 1985, 1987).

\section{Öncelikler ve Dini Tercihler}

İnsan sermayesi yaklaşımı önceki dini faaliyetleri bireylerin dini değeri kollektif olarak üretme yeteneğini artıncı bir unsur olarak gördüğü halde, talepyönü perspektifleri önceki dini tecrübelerin kişilerin dini metalara yönelik arzulanı etkilediğini iddia etmektedir. Bu baksş açısınun, değişen tercihler üzerine kurulu iktisat teorisi alanunda sağlam köklere sahip olduğuna işaret etmemiz gerekir (krş. Von Waizsaker 1971, Elster 1983). Genellikle dini tecrübelerin alışılmış dini metalara yönelik talepleri artırdığı ve tercihlerin uyarlanabilir olduğu söylenir (Sherkat 1997, 1998, Sherkat \& Wilson 1995). Dini 
karşliklara, açıklamalara ve kurumlara aşinalık -bireyleri dini metalar konusunda daha iyi değer üretebilir kalmaktan çok- geleneksel inanç ve bağlluklan daha değerli kular. Tercihlerin değişmesi her zaman status quo lehine sonuçlar ortaya çıkarmaz. Çünkü bireyler eğitim, kültürler arası ilişki, coğrafi hareketlilik, sosyal hareketlere katılım ya da sosyal hareketlilik gibi sosyal bağlar ya da değișen yaşam koşullan sayesinde yeni bilgiler edindiğinde alternatif tercihleri öğrenebilir. Aynca din arayanlar çoğunlukla yeni karşllklar ve açıklamalar lehine alışlmış dini metalanı reddedilmesiyle sonuçlanan uyum karşıtı tercihlere sahiptir (Sherkat 1997).

Sherkat ve Wilson (1995) ergenlik dönemine özgü dini inançlann özellikle kutsal kitabın yanulmazlğğ- din değiştirenlerin liberal gruplar yerine muhafazakar mezhepleri tercih etmesi konusunda tahminde bulunmays kolaylaştıracağına işaret etmektedir. Aynca bu durum önceki dini katulım düzeylerinden bağımsız olarak muhafazakar gruplann liberal gruplara tercih edilme olasllı̆ını yükseltirken dinden dönme olasiluğın düsüurmektedir. Üstelik bütün bunlar hem insan sermayesinin ve hem de önceliklerin din konusunda karar vermeyi etkilediğini göstermektedir. Anne-baba ve cemaatler araculğıyla gerçekleşen dini sosyalleşme belli başh dini metalara yönelik tercihlerin gelişiminin habercisi olmakta ve bu durum daha sonraki dini katllum ve kabulleri doğrudan yönlendirmektedir (Sherkat 1998, Sherkat \& Wilson 1995). Statü hareketliliğinin dini tercihler üzerindeki etkisi kısmen -Weber'in statü gruplan karşısında farklı teodiselerle ilgili olarak kullandığı kavram hatırlatan- yeni tercihlerden kaynaklanabilir (Sherkat \& Wilson 1995). Miller ve Hoffman (1995) muhtemel tercihler yoluyla dini davranışlann nasil tahmin edilebileceğini ve muhtemel davranışlar konusundaki cinsiyet farklleklannın dindarlıkla ilgili cinsiyet farklılıklanıın açıklanmasına nasıl katkıda bulunabileceğini göstermektedir. Zira dini inançlar ve davranışlar yanlış olabilme ihtimaline sahiptir. Çünkü, dini inanca bağh kalındığı sürece hemen hemen hiç kaybetme riski yoktur. Risk almak istemeyen bireyler, işledikleri hatanun sonsuza kadar olumsuz neticelerine katlanmak yerine Tann'ya karşı saygll olmayı tercih ederler. Aynca, yakın zamanda yapılan araştırmalar, tercihlerin dinamik doğas1 ve dini piyasa davranışı konusundaki yol gösterici rolünü, yapı teorileri ile ilişkilendirmektedir (Sewell 1992). Dini katılum dini kaynaklarla karşllkkl etkileşimi zorunlu kılarken, dini öncelikler dini tercihlere rehberlik eden şemalar olarak kabul edilmektedir. Dini kaynaklarla karşllkk etkileşim genellikle dini şemalar güçlendirir. Ancak, bu durum yeni önceliklerin öğrenilmesi ile de sonuçlanabilir (Sherkat 1997, 1998). Rasyonel tercih teorileri ve yapı teorileri arasındaki karmaşık ilişkiler, aile, işyeri, eğitim, siyaset vs.'nin din üzerinde ve 
dinin toplumsal yaşamın diğer alanlan üzerindeki etkilerinin bir araya getirimesine uygun yapay bir çerçevenin yanı sıra, dini piyasalann gerek bireysel gerekse kurumsal unsurlannın birlikte değerlendirilmesine olanak sağlar.

\section{Bireyin Dini Tercihleri Üzerindeki Toplumsal Etkiler}

Tercihler üzerindeki toplumsal etkiler iktisat teorisinde önemli bir tartışma konusudur. Aynca, sosyologlar normatif baskı modelleri sayesinde bu tür değerlendirmelerin yolunu açmışlardır (Akerlof 1997, Bernheim 1995, Sen 1993). Bütün tercihler karar verme sürecini etkileyen toplumsal ilişkiler ağ 1 içerisine yerleştirilmiştir ve özellikle dini tercihler bu tür bir akul yürütme için son derece uygundur. Toplumsal etkiler dini tercihleri yönlendirdiği halde, tabiatüstü karşllklar ve açiklamalara yönelik öncelikler seçilen dini metanın çeşidi ya da niteliği konusunda kayda değer bir etkiye sahip değildir. Tercihler üzerindeki toplumsal etkilerin üç kaynağı vardır: (a) Dini tüketim başkalannı mutlu etme arzusu tarafından yönlendirildiğinde: Sempati, (b) dini davranışa motive etmek amacıyla başkalanna nasıl davranmalan gerektiği gösterildiğinde: Örnek verme ve (c) ödüller ya da cezalar (Sherkat 1997). Sempati, annebabalann ve eşlerin dini tercihler üzerindeki etkilerini açıklamak için kullanılur. Ģïnkü insanlar, genellikle dini hizmetlere ya da dini cemaatlere sevdiklerini mutlu etmek amaciyla katulular. Anne-babaya yakın olma duygusu, dinden dönme olasul̆ğı zayıflatmaktadır (Sherkat \& Wilson 1995). Annebabalar dini tercihleriyle çocuklanna ömek olmaktadır. Aynca, çocuk sahibi olma, dini katılım oranlanın artırmakta ve bireyin dinsiz olma olasılığın azaltmaktadır (Myers 1996, Stolzenberg ve diğerleri 1995, Sherkat 1998).

Dini tercihler çoğunlukla dünyevi ceza ve mükafatlarla bağlantılıdır. Dini gruplar genellikle (sosyal destek, arkadaş bulma, günlük sıkıntılardan kurtulma ve ekonomik faaliyetler gibi) çeşitli dünyevi ayrıcalıklara sahip olma konusunda hizmet gören aracı kurumlardır. Ayrica, aynı dine inanan insanlar arasındaki toplumsal bağlar, dini organizasyonlara katılımı sağlayan ortak motivasyonlardır. Bununla birlikte, dini grup dışındaki insanlarla ilişkiler, özellikle dini tercihler yeni dini hareketlerle birlikte ayrllkçı olarak değerlendirildiğinde, cemaatin üye kazanma potansiyelini düşürebilir (Stark \& Bainbridge 1985, 1987). Toplumsal bağlann, aile, iş, arkadaşlik, akraba ilişkileri ve diğer toplumsal alanlardaki bağllliklarla pekiştirildiği topluluklarda bireylere ciddi toplumsal mükafatlar verilebilir ya da egemen dini kurumlara katılmayı reddettiklerinde cezalandınlabilirler. Bu tür din dışı yaptırımlar dini gönüllülüğü sınılandırmaktadır. Afrika kökenli Amerikalılar arasında, dini çıkarlar, diğer bölgelerle karşılaşturıldığında güneydeki -özellikle kırsal güney- 
deki- dini katılım konusunda daha az tahmin edilebilir sonuçlar ortaya çıkarmaktadır. Güneyde Afrika kökenli Amerikalılara yönelik toplumsal fırsatlar, Baptist ve Metodist kiliseler tarafından sunulanlar hariç, sınurlıdır. Homogami normlan ile mekansal ve mesleki ayınm, toplumsal bağlan pekiştirerek toplumsal statü ve diğer toplumsal çıkarlardan faydalanmak için gerekli olan dini katulum düzeyini bir dereceye kadar düşürmektedir (Ellison 1995, Ellison \& Sherkat 1995, Sherkat \& Cunningham 1998). Benzer bir ömeğe, Mormonlar arasında da rastlanabilir (Philips 1998). Mormonlann kalesi Batı Intermountain bölgesinde dini katılum ve bağlllk oranlan daha yüksektir.

\section{Kilise-Mezhep Döngüsünün Açıklanması}

Stark ve Bainbridge'in $(1985,1987)$ kilise-mezhep döngüsü, dini organizasyonlardaki yükseliş ve düşüşlerin yörüngesinin belirlenmesi açısından önemli teorik bir model sunmaktadir. Onlann modeli, hem arz hem de talep unsurlanna vurgu yapmaktadır. Dini organizasyonlarn tanumlanması ve sinuflandrilması bu perspektifin anlaşılması açısından son derece önemlidir. Dini gruplar, toplumla aralanndaki gerilimin derecesine göre çeşitlilik gösterir. Kiliseler dünyevi kurumlarla neredeyse hiç gerilim yaşamazlar. Çünkü onlar, öteki dünyayı dışlayıcı açıklamalan reddederler. Mezhepler, aşkın mükafatlara özel bir erişimi elinde bulunduran nadir kurumlar olduklarını iddia ederler. Aynı zamanda bu iddialar, onların hakim toplumla gerilim içerisinde olmalanna neden olur (Stark \& Bainbridge 1985, 1987, Iannaccone, Montgomery 1988). Mezhepler, daha az imtiyazlı gruplar açısından oldukça çekicidir. Ģïnkü onlar, dünyevi kazanç ve zevklerden feragat etmenin öneminden söz eder. Dolayisıyla kaybedenlerin oran her zaman üst sınuflarda daha fazladır ve hatta toplumsal bağlulkklan sayesinde onlar üyeliğe kazandınlabilirler. Mezhepçi dini gruplar geniş bir çekim alanuna sahiptir ve herhangi bir engelleme ile karşılaşmadıklan sürece her geçen gün büyümeye devam etmektedir (Finke \& Stark 1992).

Bununla birlikte dini organizasyonlar ve onlann seçmen kitlesi statik değildir. Başanlı mezhepler, hareket kaynaklanm idare etmek ve Hz. İsa'ya itaat ederek kurtuluşa erme misyonu açısından son derece önemli olan görevleri organize etmek için büroktratik kurumlar oluşturmaktadır. Artık, bu organizasyonlann profesyonel üyeleri, hareket taraftarlanna doğrudan borçludur. Aynca bu dindar seçkinler, kendi dini arzuların bu mezheplere dikte etmeye başlayabilirler. Çünkü dindar seçkinler sürekli yükselme eğiliminde olduklan için daha fazla maddi değeri olan dini metalar arayacaklardır. Aynca, dikey hareketliliğe sahip mezhep üyeleri, bu tür maddi değeri yüksek olan dini me- 
talan tercih edeceklendir. Seçkin üyelerden gelen katkılar mezhep tarafından sunulan dini metalann değişmesine de katkıda bulunabilecektir. Papaz okulla$\mathrm{n}$ ve teftiş kurullan dindar elitlerin dini metalann üretimini denetlemelerine ve papaz okullann ve papaz tayinlerini yönlendirerek ve mezhep düzenine aykurn düşünen ve hareket edenleri cezalandırarak ürün homojenliğini sağlamalanna izin vermektedir. Bu durumun nihai sonucu, öteki dünyaya ait teolojilerin yerini giderek daha çok bu dünyaya ait teolojiler ile birlikte kurtuluşu merkeze alan bir misyona bırakması ve seküler kaygılar üzerinde yoğunlaşma eğiliminin artmasıdır (Stark \& Bainbridge 1985, 1987, Montgomery 1996, Finke \& Stark 1992).

Mezhepler gerilim düzeylerini düşürerek kiliseleşme eğilimi sergilerken, pek çok mezhep üyesi orijinal mezhebin öteki dünyaya ait dinini benimsemektedir. Bazı üyeler önceki mezheplerini bırakmakta ve yüksek gerilim düzeyini devam ettiren gruplara katılarak ötekini dışlayııı tabiatüstü karşlıklar ve açıklamalar sunmaktadır. Diğer mezhep üyeleri değişikliklere karşı seslerini yükseltebilir. Bu durum mezhepten kovulma ya da atulma ve yeni bir mezhebin kurulması ile sonuçlanabilir. Metodistler bu konuda Amerika'da klasikleşmiş bir ömektir. 19. yüzylın başlannda öteki dünyaya ait kurtuluş yönelimli bir mezhep olarak ortaya çıkan Metodistler, zamanla papaz okullan kurdular, tam gün çalışan maaşlı papazlar istihdam etmeye başladılar, bireysel mükemmellik ilkelerini kabul etmediler ve $\mathrm{Hz}$. İsa'ya itaat ederek kurtuluşa erme misyonunu temkinli bir sistematik teoloji ile değiştirdiler. Mezhepçi hareketler dini ürünlerini değiştirdiklerinde parçalandılar ve bağımsız metodistleri ve "eski zaman dinini" geri getirme yollan arayan çeşitli kutsal mezhepleri kurdular (Finke \& Stark 1992). Bazen öteki dünyaya ait mükafat arayışı içinde olanlar aradıklann yeni dinlerde -kültler- buldular. Yenilikçi mezhepler ve/veya yeni kültler piyasadaki boşluğu canl bir şekilde öteki dünyaya ait tabiatüstü mükafatlarla doldurdular ve böylece aksi takdirde kilisevi hareketlerin nüfuz elde etmesine yol açabilecek sekülerleşmeyi sınurlandırdılar.

\section{Sikılik ve Etkililik}

Kanter'in (1972) cemaatsel hareketler üzerine yaptığ araştırmalarla birlikte bilim adamlan üyeleri üzerinde sıkı talepleri olan gruplann daha başarlı olduklannı ve bu başannın grup üyelerinin rasyonel eylemlerinde yattığın fark etti (Hall 1988b). Bu konuda dini hareketlerin hiçbir istisnası yoktur. Aynca son zamanlarda sosyal bilimciler dini hareketlerdeki sıkulğın ortaya çıkardığı üretici fonksiyonlan açıklamak için teoriler geliştirmektedir. Kelley'nin (1972) sıkı dini gruplann geliş̧mi ve güçlenmesi ile ilgili araştırmasına dikkat çeken Ionnaccone (1992, 1994), dini değerin kollektif üretimi konusundaki artışa 
işaret ederek sıkılı̆ıı avantajlarını açıklamaktadır. Sıkı dini gruplar, dini bağ lı̆ı daha güçlü olan üyelerin kollektif üretim çabalan üzerinden kazanç elde etmeye çalışan verimsiz üyeleri çıkardılar. Ionnaccone, sık kiliselerin üyelerinden özveride bulunmalann ve yükümlülüklerini yerine getirmelerini istedikleri için, tembel üyelerin bu kiliselere girmeye cesaret edemediklerini ve böylece kendini daha fazla adamış üyelerin ellerindeki daha yüksek sermaye sayesinde daha fazla dini fayda sağladıklann if ade etmektedir. Bununla birlikte, dini bağlllı̆ı olan üyeler bazı dünyevi değerleri feda etmektedir. İnanalar, cemaat üyelerinin ayn derecede fedakarlıkta bulunarak el birliği ile ürettiği pek çok dini metanun bedelini ödemektedir. Bu tezler, dışlayıcı muhafazakar dini gruplann (Finke \& Stark 1992) ksmi başarlann, muhafazakar gruplarda kaynak hareketinin daha yüksek olduğunu (Ionnaccone ve diğerleri 1995) ve Katolik dini gruplann (Finke 1997) hareketliliğinde meydana gelen değişimleri gösteren tarihsel araştırmalara son derece uygundur. Aynca, Ionnaccone'in modeli fedakarlikların ya da yükümlülüklerin haddinden fazla yüksek olduğu durumlarda ve düzenlemelerin bazı dünyevi çıkarlan zorunlu kıldığı zamanlarda ortaya çıkan sorunlara işaret etmektedir (Ionnaccone \& Miles 1990). Daha faal bireyler sıkı gruplan tercih ederken, dini bağlluğı daha zayf bireylerin daha az sorumluluk yükleyen liberal gruplara katıldıklan görülmektedir (Sherkat \& Wilson 1995).

"Sık kilise" tezi hem etkili hem de tartışmalıdır (Chaves 1995, Demerath 1995, Ellison 1995, Ionnaccone 1995b, Marwell 1996, Spickard 1998) Aynca, bu tez teorik ve pratik açıdan eleştirilmektedir. Wallis (1991) çaba sarfetmeksizin kazanç elde etmenin katulım değerini artıran maddi tercihler tarafından sınırlandırıldığına ve bunun sadece samimi katulımcılann faydalanabileceği bir süreç olduğuna dikkat çekmektedir. Marwell (1996) fedakarlğın sıkullk ile kaynak hareketinin birleşmesi sonucu ortaya çıktığın ve bu nedenle kurumsal güce bağlliktan farklı olduğunu iddia etmektedir. Tullock (1996) başkalarının sırtından kazanç elde etmenin önemli olmadığın, çünkü dini metaların yangın sigortası gibi özel metalar olduğunu ifade etmektedir. Aynca, dini ve dünyevi değerin ortak maksimizasyonu, Ionnaccone'ın iddialanndan daha uygun olabilir -kişi dindar bir muhafazakar Protestan, Ortodoks Yahudi ya da Mormon olabilir ve hala seküler yaşamın bütün maddi yönlerinden faydalanmayı sürdürebilir. Bu teori, ortak üretim olasllğın ortadan kaldırarak Ionnaccone'in iddialarını çürütmektedir.

Aynca, kutsal kitaplara yönelik tercihler, dini katılımın önemli belirleyicileri arasında yer alabilir (Sherkat 1997). Aslında sıkı dini organizasyonlara üye olanlarnn çoğu, dinsizlerle ilişkileri koparmayı ya da sarhoşluk, homoseksüellik ya da evlilik dışı ilişkiden uzak durmayı bir fedakarlık olarak değerlendir- 
memektedir. İnsanlar bu tercihleri onaylayan dini gruplan seçebilir. Değerli açıklamalar sunan dışlayıcı anlam sistemleri, "sıkı" gruplanın sağladığı en önemli fayda olabilir (Stark \& Bainbridge 1985, 1987). Aynca bu inançlar, özel metalara benzeyenler dışında, kollektif üretimle bağlantılı değildir. Ampirik bulgular, dini grupların gelişimi ve başansı ile ilgili alternatif yorumlara ve sıkaluk ile gelişme arasındaki eksik ilişkiye dikkat çekmektedir. Perin ve Mauss (1993) tartışlmaz güç ve büyüklüğe sahip mega kiliselerin üyeleri tarafından üstlenilen fedakarlıklara ya da yükümlülüklere ilişkin hemen hemen hiçbir bulguya rastlayamadıklarını ifade etmektedir. Kilisenin gelişimi konusunda yapılan araştırmalar, gittikçe genişleyen çeşitli "sıkı" kiliseler hakkında makul bir kanıt sağlayamadilar (Smith 1992, Lazerwitz 1995). Aynca pek çoklan, büyüme ve gücün, yaş, pazarlama teknikleri, coğrafi konum ve doğum oranlannın bir fonksiyonu olmasının daha muhtemel olduğunu iddia etmektedir (Roozen \& Hadaway 1993).

\section{Coğulculuk ve Dinsellik}

Dini çoğulculuğun dinselliğe etkisi, şiddetli tartışmalara konu olmaktadır. Dini birliğin dindarlı̆ı artıracağını ve dini kurumlan güçlendireceğini ileri süren Durkheimci teorisyenlerin aksine (Berger 1967), arz-yönü teorisyenleri dini çoğulculuğun din piyasasındaki hareketliliği artırdığın iddia etmektedir. Arz-yönü teorisyenleri, Adam Smith'in görüşlenine dayanarak, dini tekelciliklerin yüksek fiyatl ve kalitesiz dini metalar ürettiklerini ileri sürmektedir (Finke \& Stark 1988, 1992, Finke ve diğerleri 1996, Ionnaccone 1991). Sağluklı bir dini piyasada çeşitli tekliflere ihtiyaç duyulur. Çünkü dini tercihler statü gruplan, etnik köken, sunf durumu ve yaşam deneyimlerine bağh olarak çeşitlilik gösterir (Stark \& Bainbridge 1985, 1987). Çoğulcuğun dini ekonomilerin doğal devleti olduğu iddia edilmektedir. Dini tekelcilikler sadece devletin himayesiyle ayakta kalabilir. Devlet yardımlannın avantajın kullanan kurumsallaşmış kiliseler (ehliyetsiz de olsa) din adamlanna yaşam boyu iş garantisi sunmakta, önemli kişilere eleman tahsis etmekte ve son derece gösterişli binalar vs. vermektedir. Ancak yarım gün çalşsan papazlar ve gönüllüler yerel cemaatlerde daha iyi hizmet görebilir. Çünkü onlar cemaat üyelerinin yaşam deneyimlenine katılırlar. Rekabet, kurumlan daha etkili hale getirir. Böylece müteşebbis satıcılar dini ürünleri -dindar elitlerin tercihlerine göre belirlemekten çok kurum üyelerinin arzularnna uyarlayarak- gayretle pazarlamaya çalışırlar (Finke \& Stark 1992, Iannaccone 1991).

Birleşik Devletler'den ve başka yerlerden elde edilen ciddi bulgular, dini tekelcilikler ve devlet düzenlemelerinin olumsuz etkisini, buna karşllk çoğulculuğun olumlu etkisini gözler önüne sermektedir (Chaves \& Cann 1992, Chiristiano 1987, Finke \& Stark 1988, Finke ve diğerleri 1996, Hamberg \& 
Pettersson 1994, Iannaccone 1991, Olds 1994, Stark \& Iannaccone 1994). 19. yüzylda Birleşik Devletler'de dini çoğulculuk kilise üyeliğini ve din adamı talebini artırmıştır. Çünkü, rekabet ortamlannda Katolik kiliseleri üyelenini harekete geçirme konusunda daha etkili ve dini metaların pazarlama konusunda daha yaraticıdır (Stark 1998, Stark \& McCann 1993). Stark (1997) Birleşik Devletler'de serbest din piyasasına maruz kalmanın, birinci kuşak Alman göçmenlerin niçin kısmen daha dinsiz ve fakat üçüncü kuşağın niçin diğer Amerikallardan farksı olduğunu açıladağın iddia etmektedir. Aynca, dini özgürlük, Eski Sovyetler Birliği (Greeley 1994) ve Latin Amerika'daki (Gill 1996) dini gruplann saylanndaki artışın yanı sıra, Avrupa'da (Stark 1993) yeni dini hareketlerin ortaya çıłışıłla da bağlantılddır. Bununla birlikte, bazı bilim adamlan 20. yüzylln başlarnnda ve daha sonralan Birleşik Devletler'deki eyaletlerde çoğulculuk ve kilise üyeliği arasında tersine bir ilişki olduğunu ortaya koydu (Blau ve diğerleri 1992, 1993, Breault 1989, Land ve diğerleri 1991). Bu sonuçlar, analitik yöntem ve değerlendirmelere daha uygundur. Çoğulculuğun üyelik oranlar üzerindeki olumlu etkisi, Katoliklerin yüzdelerini kontrol altına almay gerektirmektedir. Eleştirmenler bu tür problemlerin çoğulculuğun üyelik üzerinde kısmen olumlu bir etki yaratmasına yol açtğın ve bağhllk oranlan konusunda Katoliklerle ilgili rakamlann olumlu etkisinin çoğulculuk tezlerine uygun olmadığın iddia etmektedir. Arz-yönü teorisyenleri, bunlann önemli sorunlar olmadığın, çünkü Katolisizmin kendi içinde çeşitliliğini koruduğunu ve bu durumun olumlu etkisinin teoriyle bağdaştığın ileri sürmektedir. Diğer taraftan, çoğulcululuk taraftarlan ikna edici bir biçimde şehirlerin uygun analiz birimleri olduğunu savunmaktadır. Eyaletler haddinden fazla büyüktü ve -özellikle otomobilin gelişinden önce- yerel tekelcilikleri gizleyebiliyordu. Dini özgürlüğün zamanlaması, 19. ve 20. yüzyllla ilgili bulgularla karşılaştrrldığnnda açıklayıcı bir rol oynamaktadır. Son zamanlarda özgürleşen dini piyasalar gittikçe artan rekabete daha uygun gibi görünmektedir. Aynca, çoğulculuğun olumlu etkilerinin de muhtemel sınırla$\mathrm{n}$ vardır. Birkaç rekabetçi kurumun dışında çoğulculuğun dini bağllllk üzerinde hemen hemen hiçbir ekstra olumlu etkisi bulunmamaktadır.

\section{Sonuç}

Dinin sosyolojik açıdan yeniden keşfi, kültürün diğer alanlanna da ilginin yeniden canlandı̆̆ı bir zamana rastlamaktadır. Kültürel faktörleri bu disiplinin kenarna iten yapisal fonksiyonel teoriler ve Marksist teleolojiler, modem sosyolojinin çeşitli açlardan küresel çerçevesinin belirlenmesinde daha az görünür hale gelmiştir. Dini piyasa araştırmalanınn teorik çatısı, 1980 'lerin 
ortalanndan itibaren huzlı bir gelişme kaydetmiştir. Bu noktada açıkça eksikliği hissedilen, farklı düzeylerdeki değerlendirmeler arasında teorik ve ampirik bir bağlantı kurmaya yönelik ciddi girişimlerin olmayışıdır. Gelecekte yapılacak araştırmalar şunlara ihtiyaç duyacaktur: (a) Ev halkının verimliliği üzerinde tercih değişikliklerinin kısmi etkilenini ortaya çıkarmak, (b) dini değerin ortak üretildiği durumlan, özsel değere sahip özel bir fayda sağlandığı durumlardan ayırt etmek, (c) tercihler üzerindeki toplumsal etkilerin kaynaklannı ve büyüklü̈̆ünü açıkça belirtmek, (d) kurumsal süreçlerin piyasa dinamikleri üzerindeki etkisini (bireyin tercihleri ve bağıs toplama konusunda mezhep çatışmalan ve kurumsal baskının etkisi gibi) incelemek ve (e) mevcut tercih/insani sermaye yaplannı ve kurumsal faktörleri bir şekilde göz önünde bulunduran bağış piyasaların modellemek. Çok-düzeyli modelleme konusundaki çeşitli gelişmeler bu tür araştırmalar mümkün kulabilir. Ancak, günümüzde veri açı̆ğ ve işletimsel problemler bu konuda yaplabileceklari sınurlandırmaktadır. Benzer bir şekilde, dini inançlar, bağlllklar ve onlann etkileri üzerine yapılan araştırmalar, yüksek kalite eksikliği ve toplanan bilgilerin ulusal düzeyde kalmasından dolayı istenen sonuçlan ortaya çıkaramamıstır. Pek çok veri toplama girişimi dini faktörleri bütünüyle göz ardı etmiş, diğer bazılan ise, sadece dini kimlik ve/veya belirli bir yer ve belirli bir zamandaki dini katılım üzerinde etkili olan tek bir faktörün kabaca ölçümü amaçlamıştır. Bu veri eksikliği, din sosyolojisi araştırmalan açısından, özellikle araştırma sorulan urki ve etnik ya da farkl niteliklere sahip dini alt gruplar üzerinde odaklandığında, ciddi sorunlar ortaya çıkarmaktadır.

\section{Bibliyografya}

- Aho JA 1990. The Pditios of Righteons ness: Idabo Omistian Patriotism Seattle: Univ. Wash. Press.

- Akerlof GA. 1997. "Social Distance and Social Decisions". Econometria 65:1005-27.

- Alwin DF. 1986. "Religion and Parental Childrearing Orientations: Evidence for a Catholic Protestant Convergence". Am J. Socid. 92: 412-440.

- Bankston CI, Zhou M 1996. "The Ethnic Church, Ethnic Identification, and the Social Adjustment of Vietnamese Adolescents". Rev Relig. Res. 38: 18-37.

- Barkun M. 1994. Religion and the Racist Right. Chapel Hill: Univ. North Carolina Press.

- Bartkowski JP. 1997. “Debating Patriarchy. Discursive Disputes over Spousal Aurhority among Evangelical Family Commentators". J. Sa Stud Relig. 36: 393-410.

- Bartkowski JP, Ellison CG. 1995. "Divergent Perspectives on Childrearing in Popular Manuals: Conservative Protestants vs. the Mainstream Experts". Socid Relig. 56: 21-33.

- Batson CD, Schoenrade PA, Ventis WL. 1993. Religion and the Indiridual $A$ Social Psyobological Perspectize. New York: Oxford Univ. Press.

- Bedell KB. 1997. Yearbook of A merican and Canadian Chorder. Nashville, TN: Abingdon.

- Bernheim BD. 1995. “A Theory of Conformity”. J. Polit. Econ. 102: 841-77.

- Berger PL. 1967. The Sacred Camopy. New York: Anchor. 
- Beyer P. 1994. Religion and Globalization London: Sage.

- Billings DB, Scott SL. 1994. "Religion and Political Legitimation". A mm Reu Socid. 20: 173 202.

- Blanchard D. 1994. The Anti-Abontion Movement and the Rise of the Religions Right. New York: Twayne.

- Blau JR, Land KC, Redding K. 1992. "The Expansion of Religious Affiliation: An Explanation of the Growth of Church Participation in the U. S. A 1850-1930". S $\propto$ Sa. Res.. 21: 329-52.

- Blau JR, Redding K, Land KC. 1993. "Ethnocultural Cleavages and the Growth of Church Membership in the United States". Socid. For. 8: 609-37.

- Bradley MB, et al. 1992. "Churches and Church Membership in the United States 1990". Atlanta: Glenmary Res.

- Breault KD. 1989. "New Evidence on Religious Pluralism, Urbanism, and Religious Participation". Am Socid Reu 54: 1048-53.

- Brewster KL, Cooksey EG Guilkey DK, Rindfuss RR. 1998. "The Changing Impact of Religion on the Sexual and Contraceptive Behavior of Adolescent Women in the United States". J. Marr. Fam 60: 493-504.

- Bruce S. 1993. "Religion and Rational Choice: A Critique of Economic Explanations of Religious Behavior". Socid. Relig. 54: 193-205.

- Bryk AS, Lee VE, Holland PB. 1993. Catholic Sobools and the Common Good Cambridge, MA. Harvard Univ. Press.

- Caldwell CH, Green AD, Billingsley A. 1992. "The Black Church as a Family Support System: Instrumental and Expressive Functions". Nath J. Socid. 6: 21-40.

- Call VR, Heaton TB. 1997. "Religious Influence on Marital Stability". J. Sa Stud Relig. 36: 382492.

- Capps DA. 1995. The Crildish Song. The Religious Abuse of Crildon Louisville, KY: Westminster/John Knox.

- Casanova J. 1994. Public Religions in the Modem World Chicago, IL: Univ. Chicago Press.

- Chaves M. 1989. "Secularization and Religious Revival: Evidence from US Church Artendance Rates 1972-1986". J. Sa Stud Relig. 28: 46477.

- Chaves M. 1994. "Secularization as Declining Religious Authority". Soc Forc 72: 749-74.

- Chaves M 1995. “On the Rational Choice Approach to Religion”. J. Sa Stad Relig. 34: 98-104.

- Chaves M, Cann DE. 1992. "Regulation, Pluralism, and Religious Market Structure". Rational Soc 4: 272-90.

- Chong KH. 1998. "What It Means To Be Christian: The Role of Religion in the Construction of Ethnic Identity and Boundary among Second-Generation Korean Americans". Socid Relig. 59: 259-86.

- Christiano KJ. 1987. Religias Dizersity and Social Change A merican Cities 1890-1906. Cambridge: Cambridge Univ. Press.

- Cochran JK, Beeghley L, Bock EW. 1988. "Religiosity and Alcohol Behavior: An Exploration of Reference Group Theory". Socid Formom 3: 256-76.

- Cochran JK, Wood PB, Arneklev, BJ. 1994. "Is the Religiosity Delinquency Relationship Spurious? A Test of Arousal and Social Control Theories". J. Res. Crime Delinq. 31: 92-123.

- Coleman JS. 1988. "Social Capital in the Creation of Human Capital". A m J. Socid. 94: 95-120.

- Cook EA, Jelen TG, Wilcox C 1992. Betreen Tro Absolutes: Public Opinion and the Pditio of Abortion Boulder, CO: Westview.

- Cornwall M. 1989. "The Determinants of Religious Behavior: A Theoretical Model and Empirical Test". Soc Forc 68: 572-92. 
- Curry TR. 1996. "Conservative Protestantism and the Perceived Wrongfulness of Crimes". Crimindogy 34: 453-64.

- Curtis KT, Ellison OG. 1998. "Religious Heterogamy and Spousal Conflict among US Married Couples". Paper Presented at the Annu. Meet. Midsouth Sociol. Assoc., Lafayette, LA

- Darnell A, Sherkat DE. 1997. "The Impact of Protestant Fundamentalism on Educational Attainment". Am Socid. Reu 62: 306-16.

- Davidman L. 1990. Tradition in a Rootles World. Women Tum to Onthodox Judaism Berkeley. Univ. Calif. Press.

- Davis NJ, Robinson RV. 1996. "Are the Rumors of War Exaggerated? Religious Orthodoxy and Moral Progressivism in America?” Am J. Socid. 102: 756-87.

- De Vaus D, Mcallister I. 1987. "Gender Differences in Religion: A Test of the Structural Location Theory". Am Socid. Reu 52: 172-81.

- Demerath NJ. 1995. "Rational Paradigms, a Rational Religion, and the Debate over Secularization". J. Sa. Stud. Relig. 34: 105-12.

- Demmit KP. 1992. "Loosening the Ties That Bind: The Accomodation of Dual-Earner Families in a Conservative Protestant Church". Reu Relig. Res. 34: 3-19.

- Dimaggio P, Evans J, Bryson B. 1996. "Have Americans Social Attitudes Become More Polarized?" A m J. Socid.102: 690-755.

- Dobbelaere K. 1985. “Secularization Theories and Sociological Paradigms: A Reformulation of The Private-Public Dichotomy and the Problem of Social Integration". Socid. A nal. 46: 377-87.

- Donahue MJ, Benson PL. 1995. "Religion and the Well-Being of Adolescents". J. Soc Issues 51: 145-60.

- Douglas M. 1982. "The Effects of Modernization on Religious Change". Daedalus 111: 1-19.

- Durkin JT, Greeley AM 1991. "A Model of Religious Choice under Uncertainty: On Responding Rationally to the Nonrational”. Ration $S \propto$ 3: 178-196.

- Ellison OG. 1991. "Religious Involvement and Subjective Well-Being". J. Health Soc Behar 32: 80-99.

- Ellison CG. 1992. “Are Religious People Nice People? Evidence from the National Survey of Black Americans". Soc Forees 71: 411-30.

- Ellison OG. 1993. "Religious Involvement and Self-Perception among Black Americans". Soc Fores 71: 1027-55.

- Ellison OG. 1994. "Religion, the Life Stress Paradigm, and the Study of Depression". In Religion in A ging and Health: Theoretical Forndations and Mechodological Frontiers. Ed. JS Levin, pp. 78 121. Thousand Oaks, CA. Sage.

- Ellison OG. 1995. "Rational Choice Explanations of Individual Religious Behavior: Notes on the Problem of Social Embeddedness". J. Sa. Stud Relig. 34: 89-97.

- Ellison OG. 1996. "Conservative Protestantism and the Corporal Punishment of Children: Clarifying the Issues". J. Sa. Saud Relig. 35: 1-16.

- Ellison OG, Bartkowski JP. 1997. Consenatize Pratetantism and the Household Division of Labor. Pap. Presented Annu. Meet. Assoc. Sociol. Relig., Toronto.

- Ellison OG, Bartkowski JP, Anderson KL. 1999. "Are there Religious Variations in Domestic Violence?" J. Fam Issues 20: 87-113.

- Ellison OG, Bartkowski JP, Segal ML. 1996. "Conservative Protestantism and the Parental Use of Corporal Punishment". S $\propto$ Forc 74: 1003-28.

- Ellison OG, Burr JA, Mccall, PL. 1997. "Religious Homogeneity and Metropolitan Suicide Rates". Soc Forc 76: 273-99.

- Ellison CG, George, LK. 1994. "Religious Involvement, Social Ties, and Social Support in a Southeastern Community". J. Sa Sud Redig. 33: 46-61. 
- Ellison OG, Levin JS. 1998. "The Religion Health Connection: Evidence, Theory, and Future Directions". Health E dax. Behau 25: 700-720.

- Ellison OG, Muller, C 1996. "Religious Involvement, Social Capital, and Adolescent Outcomes: Evidence from the NELS-88". Pap. Presented Annu. Meet. Soc. Sci. Stud. Relig., Nashville.

- Ellison CG, Musick MA, Holden GW. 1999. "The Effects of Corporal Punishment on Children: Are They Less Harmful for Conservative Protestants?". Pap. Presented Soc Sa. Surd Relig, Boston.

- Ellison CG, Sherkat DE. 1990. "Patterns of Religious Mobility among Black Americans". Socid. Q. 31: 551-68.

- Ellison OG, Sherkat DE. 1993a. "Obedience and Autonomy. Religion and Parental Values Reconsidered". J. Sa. Stud Relig. 32: 313-29.

- Ellison OG, Sherkat DE. 1993b. "Conservative Protestantism and Support for Corporal Punishment". Am Socid. Reu 58: 131-44.

- Ellison OG, Sherkat DE. 1995. "The Semi Involuntary Institution Revisited: Regional Variations in Church Participation among Black Americans". Soc Forc. 73: 1415-37.

- Elster J. 1983. Sour Grapes: Studies in the Subrersion of Rationalizy. Cambridge: Cambridge Univ. Press.

- Evans TD, Cullen FT, Dunaway RG, Burton VS. 1995. "Religion and Crime Reexamined: The Impact of Religion, Secular Controls, and Social Ecology on Adult Criminality”. Criminology 33: 195-224.

- Filsinger EE, Wilson, MR 1984. “Religiosity, Socioeconomic Rewards, and Family Development: Predictors of Marital Adjustment". J. Mariage Fam 46: 663-70.

- Finke R. 1997. “An Orderly Return to Tradition: Explaining the Recruitment of Members into Catholic Religious Orders”. J. Sa Stud Relig. 36: 218-30.

- Finke R, Guest AM, Stark R 1996. "Mobilizing Local Religious Markets: Religious Pluralism in the Empire State 1855-1865". Am Socid. Rev 61: 203-18.

- Finke R, Stark R 1988. "Religious Economies and Sacred Canopies: Religious Mobilization in American Cities". Am Socid. Reu 53: 41-49.

- Finke R, Stark R. 1989. "Evaluating the Evidence: Religious Economies and Sacred Canopies". Am Sociol Reu 54: 1054-56.

- Finke R, Stark R. 1992. The Chrodring of A merica. Wirmers and Losers in Our Religious Ecomomy New Brunswick, NJ: Rutgers Univ. Press.

- Finke R, Stark R 1998. "Reply: Religious Choice and Competition". Am Soc Reu 63: 761-66.

- Firebaugh G, Harley B. 1991. "Trends in US Church Artendance: Secularization and Revival, or Merely Lifecycle Effects". J. Sa Sard Relig. 30: 487-500.

- Forste RT, Heaton TB. 1988. "Initiation of Sexual Activity among Female Adolescents". Youth So. 19: 250-68.

- Freeman RB. 1986. "Who Escapes? The Relation of Churchgoing and Other Background Factors to the Socioeconomic Performance of Black Youths from Inner-City Tracts". In The Black Youth Unemployment Crisis, Ed. RB Freeman, HJ Holzer. Chicago: Univ. Chicago Press.

- Gay DA, Ellison OG, Powers DA. 1996. "In Search of Denominational Subcultures: Religious Affiliation and Pro Family Issues Revisited". Reu Relig. Res. 38: 3-17.

- Glenn ND. 1987. "Social Trends in The United States: Evidence from Sample Surveys". Pub. Opin Q 51: 109-126.

- Glenn ND. 1982. "Interreligious Marriage in The US: Patterns and Recent Trends". J. Marrage Fam 44: 555-66. 
- Goldscheider G, Mosher WD. 1991. "Patterns of Contraceptive Use in The United States: The Importance of Religious Factors". Stud Fam Plan. 22: 102-15.

- Grasmick HG, Bursik RJ, Cochran JK. 1991. "Ërender unto Caesar What is Caesarísí: Religiosity and Taxpayersí Inclinations to Cheat". Socid. Q. 32: 251-66.

- Grasmick HG, Mcgill AL. 1994. "Religion, Attribution Style, and Punitiveness toward Juvenile Offenders". Criminalogy 32: 23-45.

- Greeley A. 1989. Religious Change in A merica. Cambridge, MA: Harvard Univ. Press.

- Greeley A 1994. “A Religious Revival in Russia?” J. Sa. Sud Relig. 33: 253-72.

- Greeley A. 1997. “Coleman Revisited”. Am Behar Sa 40: 587-94.

- Greven P. 1990. Spare the Orild. The Redigious Rooss of Pronishment and the Psydrological Impact of Pbssical A buse. New York: Knopf.

- Griffin W. 1995. "The Embodied Goddess: Feminist Witchcraft and Female Divinity". Socid. Relig. 56: 35-48.

- Griffith EH, Young J, Smith D. 1984. "An Analysis of the Therapeutic Elements in a Black Church Service". Hosp. Common Psodriatry 35: 464-69.

- Griffith M 1997. God's Daughters: Eungelical Women and the Porter of Submission Berkeley: Univ. Calif. Press.

- Hadaway CK, Marler PL. 1994. "All in the Family: Religious Mobility in America". Reu Relig. Res. 35: 97-116.

- Hadaway CK, Marler PL, Chaves M. 1993. “What the Polls don't Show: A Closer Look at U.S. Church Attendance". Am Socid. Reu 58: 741-52.

- Hadden JK. 1987. “Toward Desacralizing Secularization Theory”. Soc Forc. 65: 587-611.

- Hall JR 1988a. "Collective Welfare as Resource Mobilization in Peoples' Temple: A Case Study of a Poor People's Religious Social Movement". Socid A nal. 49: 64-77.

- Hall JR 1988b. "Social Organization and Pathways of Commitment: Types of Communal Groups, Rational Choice Theory, and the Kanter Thesis". Am Socid. Reu 53: 679-92.

- Hamberg EM, Pettersson T. 1994. "The Religious Market: Denominational Competition and Religious Participation in Contemporary Sweden". J. Sa Stad Relig. 33: 205-15.

- Hammond JA, Cole BS, Beck SH 1993. "Religious Heritage and Teenage Marriage”. Reu Relig. Res. 35: 117-33.

- Harley B, Firebaugh G. 1993. “Americans' Belief in an Afterlife: Trends over the Past Two Decades".J. Sa Sad Relig. 32: 269-78.

- Heaton TB, Goodman KL, Holman TB. 1994. "In Search of a Peculiar People: Are Mormon Families Really Different?" In Contemporary Mormonism Social Science Perspectizes, Ed. Mcomwall, TB Heaton, LA Young, pp. 87-117. Urbana: Univ. Press.

- Heaton TB, Jacobson CK, Fu XN. 1992. "Religiosity of Married Couples and Childlessness". Reu Relig. Res. 33: 244-55.

- Heaton TB, Pratt EL. 1990. “The Effects of Religious Homogamy on Marital Satisfaction and Stability". J. Fam Issues 11: 191-207.

- Hertel BM, Hughes M. 1987. "Religious Affiliation, Attendance, and Support for Pro Family Issues in The United States". Soc Forc.65: 858-82.

- Hoffman JP, Miller AS. 1998. "Denominational Influences on Socially Divisive Issues: Polarization or Continuity?" J. Sai Stud Relig. 37: 528-46.

- Hoge DR, Yang F. 1994. "Determinants of Religious Giving in American Denominations: Data from Two Nationwide Surveys". Reu Relig. Res. 36: 123-49.

- Hoge DR, Johnson B, Luidens DA. 1994. Vanishing Baondaries: The Religion of Mainline Protestant Baby Boomers. Louisville, KY: John Knox. 
- Hout M, Greeley A 1987. "The Center doesn't Hold: Church Attendance in The United States 1940-1984". Am Socid Reu 52: 325-45.

- Hout M, Greeley A 1990. “The Cohort doesn't Hold”. J. Sa. Stud Relig. 29: 519-24.

- Hout M, Greeley A 1998. “What Church Officials' Reports don't Show: Another Look at Church Attendance Data". Am Socid. Reu 63: 113-19.

- Hummer RA, Rogers RG, Nam CB, Ellison OG. 1999. "Religious Involvement and US Adult Mortality". Demograph in Press.

- Hunt SA, Benford RD, Snow DA. 1994. "Identity Fields: Framing Processes and the Social Construction of Movement Identities". In New Social Movements: From Idedogy to Identity, Ed. E Lamana, H Johnston, JR Gusfield, pp. 185-208. Philadelphia, PA. Temple Univ. Press.

- Hunter JD. 1991. Culure Wars. New York: Basic Books

- Iannaccone LR. 1988. "A Formal Model of Church and Sect". Am J. Socid. 94: 241-68.

- Iannaccone LR. 1990. "Religious Practice: A Human Capital Approach". J. Sa. Stud Relig. 29:3: 297-314.

- Iannaccone LR 1991. “The Consequences of Religious Market Structure: Adam Smith and the Economics of Religion". Rationality Soc 3: 2: 156-77.

- Iannaccone IR. 1992. "Sacrifice and Stigma: Reducing Freeriding in Cults, Communes, and Other Collectivities". J. Pdit. Econ 100: 2: 271-91.

- Iannaccone LR. 1994. "Why Strict Churches are Strong". Am J. Socid 99: 1180-1211.

- Iannaccone LR 1995a. "Risk, Rationality, and Religious Portfolios". Econ Inq. 33: 285-95.

- Iannaccone LR. 1995b. "Second Thoughts: A Response to Chaves, Demerath, and Ellison".J. Sa Stud Relig. 34: 113-20.

- Iannaccone LR. 1997. “Skewness Explained: A Rational Choice Model of Religious Giving”. J. Sa Stud Relig. 36: 147.

- Iannaccone LR, Miles CA 1990. "Dealing with Social Change: The Mormon Church's Response to Change in Women's Roles". Soc Forc. 68: 1231-50.

- Iannaccone LR, Olson DV, Stark R 1995. "Religious Resources and Church Growth". Soc For. 74: 705-31.

- Idler EL. 1995. "Religion, Health, and Nonphysical Senses of Self”. Soc Fonc 74: 683-704.

- Idler EL, Kasl SV. 1992. "Religion, Disability, Depression, and the Timing of Death". Am J. Socid. 97: 1052-79.

- Idler EL, Kasl SV. 1997. "Religion among Disabled and Nondisabled Persons". II: "Attendance at Religious Services as a Predictor of the Course of Disability". J. Gerontoh: Soc Sa. 52B:306-16.

- Jarvis GK, Northcott HC 1987. "Religion and Differences in Morbidity and Mortality". Soc Sa Med 25: 813-24.

- Jelen TG. 1998. "Research in Religion and Mass Political Behavior in The United States". Am Polit Q. 26: 110-34.

- Johnson BR, Larson DB, Pitts TG. 1999. "Religious Programming, Institutional Adjustment, and Recidivism among Former Inmates in Prison Fellowship Programs". Justice Q 14: 145-66.

- Johnson DC 1997. "Formal Education vs. Religious Belief: Soliciting New Evidence with Multinomial Logit Modeling". J. Sa Stad Relig 36: 231-46.

- Johnston H, Klandermans B. 1995. Social Movements and Culture Minneapolis, MN: Univ. Minn. Press.

- Kahn JR, Rindfuss, RR, Guilkey, DK. 1990. “Adolescent Contraceptive Method Choices". Demograptry 27: 323-35.

- Kanter RM. 1972. Commitment and Commonity. Cambridge, MA: Harvard Univ. Press.

- Kelley DM. 1972. Why Conserzatize Ohordhes are Growing. New York. Harper. 
- Kelley J, De Graaf ND. 1997. “National Context, Parental Socialization, and Religious Belief: Results From 15 Nations”. A m Socid Reu 62: 639-59.

- Kimble MA 1995. "Pastoral Care". In Aging Spiritualy, and Religion A Handbook. Ed. MA Kimble, SH Mcfadden, JW Ellor, JJ Seeber, pp. 131-47. Minneapolis, MN: Fortress.

- Koenig HG, George LK, Meador, KG, Blazer DG, Ford SM. 1994. "Religious Practices and Alcoholism in a Southem Adult Population". Hoxp. Common Psydriatry 45: 225-31.

- Koenig HG, Cohen HJ, George LK, Hays JC, Larson DB, Blazer DG. 1997. "Artendance at Religious Services, Interleukin-6, and Other Biological Parameters of Immune Function in Older Adults". Int. J. Psyobiatry Med. 27: 233-50.

- Krause N. 1998. "Stressors in Highly Valued Roles, Religious Coping, and Mortality". Psydod. Aging. 13: 242-55.

- K won VH, Ebaugh HR, Hagan J. 1997. “The Structure and Function of Cell Group Ministry in a Korean Church". J. Sa. Saud Relig. 36: 247-56.

- Land KC, Deane G, Blau JR 1991. "Religious Pluralism and Church Membership: A Spatial Diffusion Model". A m Socid. Reu 56: 237-49.

- Larson LL, Goltz, JW. 1989. "Religious Participation and Marital Commitment”. Reu Relig. Res. 30: 387-400.

- Layman GC 1997. "Religion and Political Behavior in The US: The Impact of Beliefs, Affiliations, and Commitment from 1980-1994". Pub. Opin Q 61: 288-316.

- Lazerwitz B.1995. "Denominational Retention and Switching among American Jews". J. Sa. Stud Relig. 34: 499-506.

- Lechner F. 1991. “The Case against Secularization: A Rebuttal”. Soc. Forc 69: 1103-19.

- Leege DC, Kellstedt LA. 1993. Redisonering the Religious Factor in A merican Politio. Armonk, NY: ME Sharpe.

- Lchrer EL. 1995. "The Effects of Religion on the Labor Supply of Married Women". So Sa Res. 24: 281-301.

- Lehrer EL. 1996. “Religion as a Determinant of Marital Ferility”. J. Pop. Econ. 9: 173-96.

- Lehrer EL, Chiswick CU. 1993. "Religion as a Determinant of Marital Stability". Demography 30: 385-404.

- Lenski G. 1961. The Religias Factor. Garden City, NY: Doubleday.

- Levin JS. 1996. "How Religion Influences Morbidity and Health: Reflections on Natural History, Salutogenesis and Host Resistance". Soc Sa. Med 43: 849-64.

- Lincoln CE, Mamiya LH. 1990. The Black Onom in the A frican A merican Experience. Durham, NC: Duke Univ. Press.

- Manza J, Brooks C. 1997. "The Religious Factors in US Presidential Elections 1960-1992". Am J. Sacid 103:38-81.

- Marcum JP. 1986. "Explaining Protestant Fertility. Belief, Commitment, and Homogamy". Socid. Q. 27: 547-58.

- Marty ME, Appleby RS. 1991. Fundamentalism Obened Chicago: Univ. Chicago Press.

- Marwell G. 1996. “We Still don't Know If Strict Churches are Strong, Much Less Why”. Am J. Socid. 101: 1097-108.

- Mattlin JA, Wethington E, Kessler RC. 1990. "Situational Determinants of Coping and Coping Effectiveness". J. Health Soc Behar 31: 103-22.

- Mcuntosh D, Spilka B. 1990. "Religion and Physical Health: The Role of Personal Faith and Control Beliefs". Res. Sœ Sä Sand Relig. 2: 167-94.

- Mcnamara PH. 1984. "Conservative Christian Families and Their Moral World: Some Reflections for Sociologists". Socid. A nal. 46: 93-99.

- Melton JG. 1996. Engdopedia of A mrican Religions. Detroit, MI: Gale Res. 
- Miller AS, Hoffman JP. 1995. "Risk and Religion: An Explanation of Gender Differences in Religiosity". J. Sä Stud Relig. 34: 63-75.

- Moaddel M 1996. "The Social Bases and Discursive Context of the Rise of Islamic Fundamentalism: The Cases of Iran and Syria". Sociol Inq. 66: 330-55.

- Montgomery JD. 1996. "The Dynamics of the Religious Economy. Exit, Voice, and Denominational Secularization". Rational Soc 8: 81-110.

- Moore RL. 1994. Selling God Oxford, UK: Oxford Univ. Press.

- Morgan SP. 1983. "A Research Note on Religion and Morality: Are Religious People Nice People?”. Soc Forc 61: 683-92.

- Morris AD. 1984. The Origins of the Ciul Rights Moument. New York: Free Press.

- Morris AD, Mueller CM 1992. Frontiers in Social Mozement Theory. New Haven, CT: Yale Univ. Press.

- Mosher WD, Williams LB, Johnson DP. 1992. "Religion and Fertility in The United States: New Patterns". Demography 29: 199-214.

- Musick MA 1996. "Religion and Subjective Health among Black and White Elders". J. Health So Behau 37: 221-37.

- Myers SM. 1996. “An Interactive Model of Religiosity Inheritance: The Importance of Family Context ${ }^{n}$. Am Socid Rev 61: 858-66.

- Nelsen HM. 1990. "The Religious Identification of Children of Interfaith Marriages". Reu Relig. Res. 32: 122-34.

- Oberschall A 1993. Social Mocements. New Brunswick, NJ: Transaction.

- Oberschall A, Kim H 1996. "Identity and Action". Mobilization 1: 63-86.

- Olds K. 1994. "Privatizing the Church: Disestablishment in Connecticut and Massachusetts". J. Pdit. Exon. 102: 277-97.

- Olson DVA. 1998. "Comment: Religious Pluralism in Contemporary U.S. Counties". Am Sœ Reu 63: 759-61.

- Ortega ST, Whirt HP, Williams JA. 1988. "Religious Homogamy and Marital Happiness". J. Fam Issues 9: 224 39.

- Oxman TE, Freeman DH, Manheimer ED. 1995. "Lack of Social Participation or Religious Strength and Comfort as Risk Factors for Death after Cardiac Surgery in the Elderly". Psjobosom Med. 57: 5-15.

- Pargament KI. 1997. The Psyobology of Religion and Coping. New York: Guilford Press.

- Pargament KI, Ensing DS, Falgout K, Olsen H, Reilly B, Van Haitsma K, Warren R.1990. "God Help Me (I): Religious Coping Efforts as Predictors of the Outcomes to Significant Negative Life Events". Am J. Common Psydod. 18: 793-824.

- Pattillo-Mccoy M. 1998. "Church Culture as a Strategy of Action in the Black Community". Am Socid Reu 63: 767-84.

- Pearce LD, Axinn WG. 1998. "The Impact of Family Religious Life on the Quality of MotherChild Relations". Am Socid Reu 63: 81028.

- Peek CW, Lowe GD, Williams LS. 1991. “Gender and God's Word: Another Look at Religious Fundamentalism and Sexism". Soc For. 69: 1205-21.

- Perrin RD, Mauss AL. 1993. "Strictly Speaking: Kelley's Quandary and the Vineyard Christian Fellowship". J. Sa Soud Relig. 32: 125-35.

- Peshkin A 1986. "God's Choice: The Total World of a Fundamentalist School". Chicago: Univ. Chicago Press.

- Petersen LR, Donnenwerth GV. 1997. "Secularization and the Influence of Religion on Beliefs about Premarital Sex". Soc Forc. 75: 1071-89. 
- Pevey C, Williams CI, Ellison OG. 1996. "Male God Imagery and Female Submission: Lessons from a Southern Baptist Ladies' Bible Class”. Qral Socid. 19: 173-93.

- Phillips R. 1998. "Religious Market Share and Mormon Church Activity". Socid. Redig. 59: 11730.

- Pollner M. 1989. "Divine Relations, Social Relations, and Well-Being”. J. Health Soc Beharu 30: 92-104.

- Portes A. 1998. "Social Capital: Its Origins and Applications in Modern Sociology". A mon Rev Socid. 22: 1-24.

- Presser S, Stinson L. 1998. “Data Collection Mode and Social Desirability Bias in Selfreported Religious Artendance". Am Socid. Reu 63: 137-145.

- Rochford EB. 1985. Hare Krishma in A merica New Brunswick, NJ: Rutgers Univ. Press.

- Roof WC. 1989. “Multiple Religious Switching”. J. Sa. Stud. Relig. 28: 530-35.

- Roozen DA, Hadaway CK. 1993. Omord and Denominational Groweth Nashville: Abingdon.

- Rose SD. 1988. Keeping Them out of the Hands of Satarr E rangelical Sdhoding in A merica. New York: Routledge, Chapman, Hall.

- Sander W. 1993. "Catholicism and Marriage in The United States". Demography 30: 373-84.

- Sandomirsky S, Wilson J. 1990. "Processes of Disaffiliation: Religious Mobility among Men and Women". Soc Fore 68:4: 1211-29.

- Scanzoni J, Arnett, C. 1987. “Enlarging the Understanding of Marital Commitment Via Religious Devoutness, Gender Role Preferences, and Locus of Marital Control". J. Fam Issues 8: $136-56$.

- Sen A 1993. "Internal Consistency of Choice”. Econometrica 61: 495-521.

- Sewell WH. 1992. "A Theory of Structure: Duality, Agency, and Transformation". Am J. Socid. 98: 1-29.

- Sherkat DE. 1991. "Leaving the Faith: Testing Theories of Religious Switching Using Survival Models". So Science Res. 20: 171-87.

- Sherkat DE. 1997. "Embedding Religious Choices: Integrating Preferences and Social Constraints into Rational Choice Theories of Religious Behavior". In Rational Ohoice Theory and Religion Summary and A ssessment. Ed. LA Young, pp. 65-86. New York: Routledge.

- Sherkat DE. 1998. "Counterculture or Continuity? Competing Influences on Baby Boomers: Religious Orientations and Participation". S $\propto$ Forc 76: 1087-1115.

- Sherkat DE. 1999. "That They Be Keepers of the Home: The Effect of Conservative Religion on Early and Late Transitions into Housewifery". Reu Relig. Res. In Press.

- Sherkat DE, Cunninham SA 1998. "Extending the Semi-Involuntary Institution Regional Differences and Social Constraints on Private Religious Consumption among African Americans". J. Sai Stud Relig.: 383-96.

- Sherkat DE. Darnell A 1999. “The Effect of Parents' Fundamentalism on Children's Educational Attainment: Mining Differences by Gender and Children's Fundamentalism". Sa Sad Relig. 38: 23-35.

- Sherkat DE, Ellison OG. 1997. “The Cognitive Structure of a Moral Crusade: Conservative Protestantism and Position of Pornography". Soc Forc. 75: 957-80.

- Sherkat DE, Ellison CG. 1991. "The Politics of Black Religious Change: Disaffiliation from Black Mainline Denominations". Soc Forc 70: 431-54.

- Sherkat DE, Wilson J. 1995. "Preferences, Constraints, and Choices in Religious Markets: An Examinarion of Religious Switching and Apostasy". Soc Forc. 73: 993-1026.

- Shibley M. 1996. Resugent E zangedicalism in The US. Columbia: Univ. South Carolina Press.

- Sikkink D 1999. "The Social Sources of Alienation from Public Schools". Soc Forc Forthcoming. 
- Smith C. 1996a. Dismptize Religiont The Fone of Faith in Social Movemen Activism New York: Routledge.

- Smith C 1996b. Resisting Reagan. Chicago: Univ. Chicago Press.

- Smith C, Sikkink D, Bailey J. 1998. "Devotionin Dixie and Beyond". J. Sa. Sad Relig. 37: 494 506.

- Smith TW. 1992. "Are Conservative Churches Growing?”. Reu Relig. Res. 33: 305-29.

- Snow DA 1993. Shakabuku: A Study of the Nidhiren Shoshu Buddhist Moremert in A merica. New York: Garland.

- Spickard JV. 1998. "Rethinking Religious Social Action: What is Rational about Rational Choice Theory?". Socid Relig. 59: 99-115.

- Stacey J, Gerard SE. 1990. "Ëwe are not Doormats': The Influence of Feminism on Contemporary Evangelicals in The United States". In Uncertain Terrs: Negotiating Gender in A merican Culture. Ed. F Ginsberg, AL Tsing, pp. 98-117. Boston: Beacon.

- Staggenborg S. 1991. The Pro Ohaice Mouement. Oxford, UK: Oxford Univ. Press.

- Stark R 1993. "Europe's Receptivity to New Religious Movements: Round Two". J. Sa. Stud. Relig. 32: 389-97.

- Stark R. 1996a. "Religion as Context: Hellfire and Delinquency, One More Time”. Socid. Relig. 57: 163-73.

- Stark R. 1996b. The Rise of Cristianity. Princeton, NJ: Princeton Univ. Press.

- Stark R. 1997. "German and German American Religiousness: Approximating a Crucial Experiment". J. Sa Stud Relig. 36: 182-93.

- Stark R 1998. "Catholic Contexts: Competition, Commitment, and Innovation". Reu Relig. Res. 39: 197-208.

- Stark R, Bainbridge WS. 1985. The Future of Religion Secularization Recizal, and Cult Formation Berkeley: Univ. Calif. Press.

- Stark R, Bainbridge WS. 1987. A Theory of Religion Toronto: Lang.

- Stark R, Bainbridge WE. 1997. Religion, Decianoe, and Social Control. New York: Routledge.

- Stark R, Iannaccone LR. 1994. "A Supply-Side Reinterpretation of the Secularization of Europe". J. Sa. Stud Relig. 33: 230-52.

- Stark R, Mccann JC. 1993. "Market Forces and Catholic Commitment: Exploring the New Paradigm".J. Sa. Stad Relig. 32: 111-24.

- Straubridge WJ, Cohen RD, Shema SJ, Kaplan GA. 1997. "Frequent Attendance at Religious Services and Mortality over 28 Years". A m J. Pub. Health 87: 957-61.

- Stolzenberg RM, Blair-Loy M, Waite IJ. 1995. "Religious Participation in Early Adulthood: Age and Family Life Cycle Effects on Church Membership". Am Socid. Reu 60: 84-103.

- Sullins DP. 1993. "Switching Close to Home: Volatility or Coherence in Protestant Affiliation Patterns?”. Soc Forc 72: 399-419.

- Taylor RJ, Chatters LM. 1988. "Church Members as a Source of Informal Social Support". Reu Relig. Res. 30: 193-202.

- Thornton A, Axinn WG, Hill DH. 1992. "Reciprocal Effects of Religiosity, Cohabitation, and Marriage". Am J. Sacid. 98: 628-51.

- Thornton A, Camburn D. 1989. "Religious Participation and Adolescent Sexual Behavior and Attitudes". J. Mamage Fam 51: 641-53.

- Tiryakian EA. 1993. “American Religious Exceptionalism: A Reconsideration". Am Am Acad. Polit. Soc Sa. 527: 40-54.

- Tiryakian EA. 1992. "Dialectics of Modernity: Reenchantment and Dedifferentiation as Counterprocesses". In Social Ohange and Modemity Ed. H Haferkamp, N Smelser, pp. 78-96. Berkeley: Univ. Calif. Press. 
- Tittle CR, Welch MR 1983. "Religiosity and Deviance: Toward a Contingency Theory of Constraining Effects". Soc Forc 61: 653-82.

- Troyer H. 1988. "Review of Cancer among Four Religious Sects: Evidence That Lifestyles are Distinctive Sets of Risk Factors". Sœ Sci. Med. 26: 1007-17.

- Tshannen O. 1991. "The Secularization Paradigm A Systematization". J. Sa. Surd Relig. 30: 395-415.

- Tullock G. 1996. "On Group Size and the Freerider Hypothesis: Another Hypothesis". Pub. Choice 87: 185.

- Verweij J, Ester P, Nauta R. 1997. "Secularization as an Economic and Cultural Phenomenon: A Cross-National Analysis". J. Sa. Stud Relig. 36: 309-24.

- Von Weizsaker OC 1971. "Notes on Endogenous Change of Tastes". J. Econ. Theory 3: 345-72.

- Wagner MB. 1990. God's Sdhods: Choice and Compromise in A merican Society. New Brunswick, NJ: Rutgers Univ. Press.

- Wallis JL. 1991. "Church Ministry and the Free Rider Problem: Religious Liberty and Disestablishment". A m J. Econ Socid 50: 183-96.

- Warner RS. 1993. "Work in Progress toward a New Paradigm for the Sociological Study of Religion in The United States". Am J. Socid. 98: 1044-93.

- Warner RS. 1995. "The Metropolitan Community Churches and the Gay Agenda: The Power of Pentecostalism and Essentialism". Relig. Soc Order. 5: 67-94.

- Wamer RS. 1997. "Religion, Boundaries, and Bridges". Socid. Relig. 58: 217-38.

- Wamer RS, Wittner JG. 1998. Gatherings in Diaspora: Religious Commonities and the New Intrigration. Philadelphia, PA. Temple Univ. Press.

- Welch MR, Tittle CR, Petee T. 1991. "Religion and Deviance among Adult Catholics: A Test of the Imoral Communities Hypothesis". J. Sci Stud Redig. 30: 159-72.

- Westoff CF, Jones, EF. 1979. "The End of Catholic' Fertility". Demography 16: 209-17.

- Wilcox WB. 1998. "Conservative Protestant Childrearing: Authoritarian or Authoritative?". Am Socid. Reu 63: 796-809.

- Wilcox WB. 1999. "Religion and Paternal Involvement: Product of Religious Commitment or American Convention?". Pap. Presented at Ann. Meet. Am Sociol. Assoc., Chicago.

- Williams DR, Larson DB, Buckler RE, Heckmann RG, Pyle CM. 1991. "Religion and Psychological Distress in a Community Sample". Soc Sa Med 32: 1257-62.

- Williams RH 1997. Cultume Wars in A merican Pditis. New York: Aldine De Gruyter.

- Williams RH, Blackburn J. 1996. "Many are called but Few Obey: Ideological Commitment and Activism in Operation Rescue". In Disnptize Religion The Foree of Faith in Social Mowement Activism Ed. CSmith, pp. 167-88. New York: Routledge.

- Wilson J, Janoski T. 1995. "The Contribution of Religion to Volunteer Work". Socid. Relig. 56: 137-52.

- Wilson J, Sherkat DE. 1994. "Returning to The Fold". J. Sa Stud Relig. 33: 148-61.

- Woodberry RD. 1998. "When Surveys Lie and People Tell the Truth: How Surveys Oversample Church Artenders". Am Socid. Reu 63: 119-22.

- Woodberry RD, Smith C 1998. "Fundamentalism et al". A rmu Reu Socid. 24: 25-56.

- Wuthnow R. 1988. "Sociology of Religion". In Handbook of Socidogy. Ed. NJ Smelser, RS Burt, pp. 473-509.

- Wuthnow R 1991a. Acts of Compassion Princeton, NJ: Princeton Univ. Press.

- Wuthnow R 1991b. Berweon States and Markes. Princeton, NJ: Princeton Univ. Press.

- Wuthnow R 1994. Sharing the Joumey. Support Grougs and A meric's New Quest for Commonity. New York: Free Press. 
- Wuthnow R. 1995. Leming to Care Elementary Kindness in an Age of Indifference. New York: Oxford Univ. Press.

- Yang F. 1998. "Chinese Conversion to Evangelical Christianity. The Importance of Social and Gultural Contexts". Socid Relig. 59: 237-59.

- Young LA 1997. Rational Oxace Theory and Religion Summary and Assessment. New York: Routledge.

- Zald MN. 1982. "Theological Crucibles: Social Movements in and of Religion". Reu Relig. Res. 23: 317-36. 